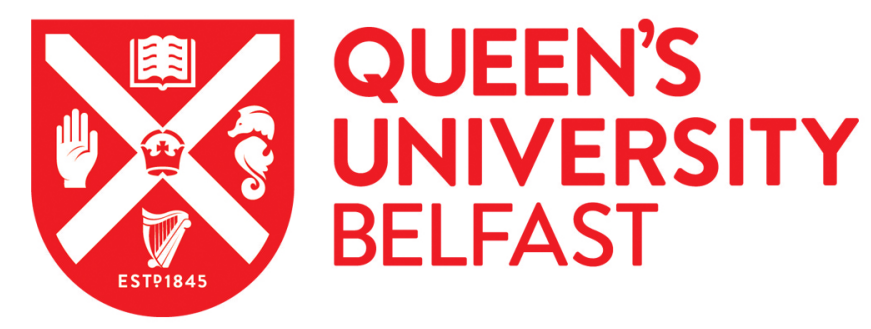

\title{
High-resolution geochemical record of environmental changes during MIS 3 from the northern Alps (Nesseltalgraben, Germany)
}

Mayr, C., Stojakowits, P., Lempe, B., Blaauw, M., Diersche, V., Grohganz, M., Correa, M. L., Ohlendorf, C., Reimer, P., \& Zolitschka, B. (2019). High-resolution geochemical record of environmental changes during MIS 3 from the northern Alps (Nesseltalgraben, Germany). Quaternary Science Reviews, 218, 122-136. https://doi.org/10.1016/j.quascirev.2019.06.013

Published in:

Quaternary Science Reviews

Document Version:

Peer reviewed version

Queen's University Belfast - Research Portal:

Link to publication record in Queen's University Belfast Research Portal

\begin{abstract}
Publisher rights
Copyright 20 Elsevier. This manuscript is distributed under a Creative Commons Attribution-NonCommercial-NoDerivs License (https://creativecommons.org/licenses/by-nc-nd/4.0/), which permits distribution and reproduction for non-commercial purposes, provided the author and source are cited.
\end{abstract}

\section{General rights}

Copyright for the publications made accessible via the Queen's University Belfast Research Portal is retained by the author(s) and / or other copyright owners and it is a condition of accessing these publications that users recognise and abide by the legal requirements associated with these rights.

Take down policy

The Research Portal is Queen's institutional repository that provides access to Queen's research output. Every effort has been made to ensure that content in the Research Portal does not infringe any person's rights, or applicable UK laws. If you discover content in the Research Portal that you believe breaches copyright or violates any law, please contact openaccess@qub.ac.uk. 


\section{High-resolution geochemical record of environmental changes}

2

3

4

5

6

7

8

\section{during MIS 3 from the northern Alps (Nesseltalgraben, Germany)}

Christoph Mayr a, b, c, *, Philipp Stojakowits d, Bernhard Lempe e, Maarten Blaauw ${ }^{\mathrm{f}}$, Volker Diersche $^{\mathrm{g}}$, Madleen Grohganz ${ }^{\mathrm{h}}$, Matthias López Correa ${ }^{\mathrm{h}, \mathrm{i}}$, Christian Ohlendorf ${ }^{\mathrm{j}}$, Paula Reimer f, Bernd Zolitschka ${ }^{\mathrm{j}}$

${ }^{a}$ Institute of Geography, Friedrich-Alexander-Universität Erlangen-Nürnberg, Wetterkreuz 15, 91058 Erlangen, Germany

b Department of Earth and Environmental Sciences, Paleontology and Geobiology, LudwigMaximilians-Universität München, Richard-Wagner-Str. 10, 80333 München, Germany ${ }^{c}$ GeoBio-Center, Ludwig-Maximilians-Universität München, Richard-Wagner-Str. 10, 80333 München, Germany

d Institute of Geography, Universität Augsburg, Alter Postweg 118, 86135 Augsburg, Germany

${ }^{\mathrm{e}}$ Chair of Engineering Geology, Technical University of Munich, Arcisstraße 21, 80333

München, Germany

${ }^{\mathrm{f}}$ Centre for Climate, the Environment and Chronology (14CHRONO), School of Natural and Built Environment, Queen's University Belfast, Belfast BT7 1NN, UK

g Schiller-Allee 1, 83457 Bayerisch Gmain, Germany

h GeoZentrum Nordbayern, Friedrich-Alexander-Universität Erlangen-Nürnberg, Loewenichstr. 28, 91054 Erlangen, Germany

${ }^{\text {i }}$ Istituto di Scienze Marine (CNR-ISMAR), Consiglio Nazionale delle Ricerche, Via Gobetti 101, 40129 Bologna, Italy

j Universität Bremen, Institute of Geography, GEOPOLAR, Celsiusstr. 2, 28359 Bremen, Germany

*Corresponding author.

E-mail address: christoph.mayr@fau.de (C. Mayr) 


\section{Abstract}

Ravine slopes at the recently discovered Nesseltalgraben site in southeastern Germany provide a unique last glacial sediment record for the Northern Calcareous Alps. The $21 \mathrm{~m}$-long profile is dominated by fine-grained lacustrine-palustrine sediments overlain by several metres of glacifluvial gravels and lodgement tills of the Last Glacial Maximum and underlain by a diamicton. The age model includes 29 radiocarbon analyses and one paleomagnetic anomaly (Laschamp event) together providing a modelled age range from c. 59 to $29.6 \mathrm{ka}$ cal BP, i.e. Marine Isotope Stage (MIS) 3. Apart from a description of the lithofacies, X-ray-fluorescence (XRF) scanning and elemental analyses provide high-resolution records of the geochemical composition. Multivariate analyses of XRF data separate $\mathrm{Ca}$ from other major elements. Carbonate contents, represented by $\mathrm{Ca}$ and total inorganic carbon, reach maxima in repeatedly occurring calcareous silty to sandy layers and are related to glacigenic origin. These indicate repeated inner-alpine local glaciations during stadials of MIS 3. Scanning electron microscopy and XRF data confirm the detrital origin of these layers. In contrast, organic matter and elements more resistant to chemical weathering ( $\mathrm{Si}, \mathrm{Ti}, \mathrm{Zr}$ ) accumulated during interstadials and concurrently elevated $\mathrm{Rb} / \mathrm{Sr}$ ratios indicate intensified weathering. The high-frequency proxy variations determined for Nesseltalgraben reflect interstadial-stadial climate variability comparable with oxygen-isotope records from Greenland ice cores and Alpine speleothems. Thus, Nesseltalgraben is among the very few independently dated sediment records from continental Europe covering the entire MIS 3 and reflecting the full Dansgaard-Oeschger climate variability.

Keywords: Pleistocene, Paleoclimatology, Glaciation, Central Europe, Dansgaard-Oeschger cycles, Middle Würmian, Lacustrine-palustrine sediment, Greenland interstadials, Grain-size analyses, Radiocarbon dating

\section{Introduction}

Sediment deposits from the Alps prior to the Last Glacial Maximum (LGM) are scarce, because subsequent glacigenic erosion obliterated most of them (Ivy-Ochs et al., 2008). Especially the period immediately before the LGM is one of the least explored of the entire last glacial cycle in the Alpine realm (Heiri et al., 2014). This period, referred to as the Middle Würmian, lasted 
approximately from 73 to $29 \mathrm{ka}$ BP (kiloyears before present) (Van Husen, 2000) and thus covers Marine Isotope Stages (MIS) 4 (71 to $57 \mathrm{ka} \mathrm{BP}$ ) and 3 (57 to $29 \mathrm{ka} \mathrm{BP}$ ) (Lisiecki and Raymo, 2005). While MIS 4 represents a major cooling phase in the Greenland ice core record, MIS 3 is characterised by rapid transitions between stadial and interstadial conditions known as Dansgaard-Oeschger cycles or Greenland stadials (GS) and interstadials (GI). 18 GIs are known for MIS 3, consecutively numbered GI 4 to GI 17-2 (Blockley et al., 2014; Rasmussen et al., 2014). Outside of Greenland, interstadials of MIS 3 have been identified, e.g. in independently dated loess records (Moine et al., 2017), lake sediments (Duprat-Oualid et al., 2017), and speleothems (Wang et al., 2001; Spötl and Mangini, 2002; Moseley et al., 2014). However, dating uncertainties, hiatuses, inadequate resolution or inappropriate proxies often delimit the detection and assignment of proxy variations to GIs in continental sediment records (Blaauw et al., 2010), especially in the Alpine realm. Therefore, presently only a few Alpine sediment records of MIS 3 age are available that mirror Greenland ice-core climate variability. Most of them are located in the western (Wohlfarth et al., 2008) or southeastern Prealps and the Alpine foreland (Pini et al., 2010; Monegato et al., 2011). In contrast, MIS 3 records from the northern Alpine region are frequently incomplete or show hiatuses, e.g. at Füramoos (Müller et al., 2003), Baumkirchen (Barrett et al., 2017a), and Unterangerberg (Starnberger et al., 2013). Pollen records are commonly used for inferring interstadial conditions for these archives (Müller et al., 2003; Burga, 2006; Barrett et al., 2018). However, the sedimentary setting during stadial conditions was often unfavourable for pollen preservation in this region, frequently leading to discontinuous pollen records. To overcome these difficulties, we applied highresolution geochemical analyses to the recently discovered sediment record of Nesseltalgraben in the Northern Calcareous Alps (SE-Germany), an approach rarely used for the investigation of Middle Würmian sediments from the Alps (Kylander et al., 2011; Barrett et al., 2017a).

\section{Study area}

The site Nesseltalgraben $\left(47^{\circ} 39.4^{\prime} \mathrm{N}, 13^{\circ} 02.8^{\prime} \mathrm{E}\right)$ is located at the northern end of the inneralpine Berchtesgaden basin, $4 \mathrm{~km}$ northeast of the city of Berchtesgaden and $15 \mathrm{~km}$ south of Salzburg (Austria). The Nesseltalgraben is an eastern tributary ravine to the valley of the river Berchtesgadener Ache draining the Berchtesgaden basin. In its upper reaches, outcrops of last glacial age were uncovered by erosion after extreme rainfall events in summer 2013. These outcrops are the object of ongoing sedimentological investigations (Mayr et al., 2017). 
Geologically, the site is located in the Northern Calcareous Alps in a complex tectonic setting (Fig. 1). It is positioned on the Lower Juvavic nappe consisting of a tectonic melange of Permian-Early Triassic evaporitic rocks (anhydrites, gypsum, claystones, halite) of the Haselgebirge Formation (Fm.) (Spötl, 1988) intermingled with up to km-sized carbonate blocks of the Middle-Late Triassic Hallstatt Fm. (Pichler, 1963; Kellerbauer, 1996). To the west of the site, the Upper Juvavic nappe is bordering which mainly consists of Middle-Late Triassic carbonates (Wetterstein Fm., Dachstein Fm.) underlain by shales and sandstones of the Lower Triassic Werfen Fm.. To the south and east the Tyrolic nappe adjoins, consisting of Triassic and Jurassic carbonate rocks as well as of Cretaceous clastic series. Extensive moraine deposits, predominantly from the LGM, cover large parts of the research area (Fig. 1). The glacier thickness during this period was around $700 \mathrm{~m}$ in the closer surroundings of the Nesseltalgraben site (Fischer, 1988). Quaternary sediments of pre-LGM time in the Berchtesgaden basin are mainly restricted to conglomerates, gravels and breccia attributed to Rissian and MindelianRissian ages (Fig. 1). A sedimentary basin filled with fine-grained lacustrine-palustrine, coarsegrained (glaci-)fluvial deposits, and tills existed at the Nesseltalgraben site from at least MIS 5c until the LGM (Mayr et al., 2017). Previous research on these lacustrine-palustrine sediments provided a first lithological description, bulk geochemical data, and a stratigraphic inventory based on paleomagnetic data, palynology, and ten radiocarbon ages with a range from $>51.5$ to $27.1 \mathrm{ka} \mathrm{BP}$ (Mayr et al., 2017). However, due to age reversals and low resolution, the previously published age model was recognized as insufficient for comparison with other highresolution paleoclimate records.

The aims of this study concentrate on revising and improving the previous age model and to obtain high-resolution geochemical records for paleoclimatic reconstructions from the Nesseltalgraben profile. To achieve these goals, plant macrofossils were selected from the sediment and different pre-treatments for ${ }^{14} \mathrm{C}$ dating were tested. Moreover, we applied XRF techniques and organic geochemical analyses to provide a high-resolution geochemical record for MIS 3 in the northern Alps. Additionally, grain-size and scanning electron microscope analyses were carried out to categorize lithofacies types and characterize the sedimentary environment.

\section{Material and methods}

\subsection{Sampling of sediment profiles}


The outcrops sampled were located on the steep walls of the Nesseltalgraben ravine and are exposed over a horizontal distance of c. $50 \mathrm{~m}$ (sections B, C, D in Mayr et al., 2017; Fig. 2). Prior to sampling, surfaces of the outcrops were cleaned by thoroughly removing outermost weathered layers manually with digging tools. Sediment bars were carved with scrapers in the cleaned sediment surface and sampled using U channels (UD steel profile $28 \times 27 \mathrm{~mm}, 0.6 \mathrm{~mm}$ thick, Knauf, Germany) (Fig. 2 F). In total, 40 overlapping sediment sections of 22 to $125 \mathrm{~cm}$ length were taken, labelled, thoroughly sealed with plastic film, and transported to the laboratory, where they were stored cool prior to further processing. For each sampled sediment section, the slope angle, ranging between $40^{\circ}$ and $80^{\circ}$, was determined in the field and the geographical position of marker layers was determined with a global navigation satellite system (GNSS, Leica Geosystems).

3.2 Core scanning, ED-XRF, and composite record

In the laboratory, the sediment surface of each U channel was smoothened with a utility-knife blade. Thereafter, it was photographed and scanned with a XRF core scanner (Itrax, Cox Analytical Systems, Sweden). Line scan images were recorded with crossed polarized light and a resolution of $500 \mathrm{dpi}$. XRF-spectra were recorded continuously in $2 \mathrm{~mm}$ steps and with a counting time of $5 \mathrm{~s}$ per measurement using a $\mathrm{Cr}$ tube at $30 \mathrm{kV}$ and $40 \mathrm{~mA}$. Reproducibility of XRF core scans was evaluated by five repeated scans of a $20 \mathrm{~cm}$ profile segment with varying lithology. Results revealed the reproducibility of the semi-quantitative analyses of the elements Al, Si, S, Cl, K, Ca, Ti, Mn, Fe, Zn, Rb, Sr, Zr, Pd, Cd, Sb, Ba, and La. The sum of counts of these elements was used for standardization of each element as percentage values. Only elements contributing more than $1 \%$ to the count sum in any of the samples were evaluated further, i.e. Si, S, K, Ca, Ti, Mn, Fe, Zn, Rb, Sr, and Zr. Multivariate statistics of XRF data was performed using the software PAST 3.22 (Hammer et al., 2001). After XRF scanning, the U channels were sectioned in $2 \mathrm{~cm}$ slices, which were lyophilised. The true depth for each section was calculated from the U-channel length and slope angle using the law of sines. Photographs and depths of all samples were rescaled according to the calculated true depths. A composite record was created using elemental records and marker layers as tie points for overlapping $U$ channels. The starting point of the composite profile $(0 \mathrm{~cm})$ is the top of the uppermost fine-grained sediment (Fig. 2 C). All depths are given as $\mathrm{cm}$ (or m) composite 
depth ( $\mathrm{cm} \mathrm{cd}$; $\mathrm{m} \mathrm{cd}$ ), i.e. below the coarse glacifluvial gravel of LGM age overlying the investigated predominantly lacustrine-palustrine sediment sequence.

In addition to XRF scanning, quantitative energy-dispersive XRF analyses (ED-XRF) of glass beads were applied on 24 selected sediment samples from the profile and 23 rock samples from the surroundings of Nesseltalgraben. These samples were homogenised with a vibratory disc mill (RS 200, Retsch, Germany). One fraction of each pulverised sample was put in a sample carrier (Ohlendorf et al., 2018) and analysed with the XRF core scanner. Another fraction was weighed for ED-XRF analyses on melt tablets. For that, $1.006 \pm 0.006 \mathrm{~g}$ of the dried powder (105 ${ }^{\circ} \mathrm{C}$ overnight) was heated for $12 \mathrm{~h}$ at $1030^{\circ} \mathrm{C}$ in a muffle furnace (M110, Heraeus, Germany) to remove carbon and volatiles and to determine loss on ignition (LOI). The residue was mixed with $4.830 \mathrm{~g} \mathrm{Li}_{2} \mathrm{~B}_{4} \mathrm{O}_{7}$ and $0.230 \mathrm{~g} \mathrm{I}_{2} \mathrm{O}_{5}$ as fluxing and melting agents and heated successively to $1050{ }^{\circ} \mathrm{C}$ with a fusion system (Oxiflux, CRB Analyse Service, Germany). The glass melt was cast as a tablet in a mould. After cooling, the glass tablets were analysed with an ED-XRF spectrometer (Spectro Xepos He, Spectro Analytical Instruments GmbH, Germany). Results are given as wt\%. Two granite standards were repeatedly analysed with every sample batch for quality assurance and precision specification.

\subsection{Radiocarbon dating and age model}

Macroscopic plant remains and organic debris for radiocarbon dating were collected by wet sieving of sediment slices with a $100-\mu \mathrm{m}$ steel sieve. The residue was rinsed with deionised water, lyophilised, and organic remains were isolated under a reflected-light binocular. Thereafter the remains were ultrasonically cleaned in deionised water for a few seconds and then lyophilised before undergoing pre-treatment for radiocarbon analyses.

Acid-base-wet oxidation (ABOX) treatment may provide more reliable radiocarbon dates for old samples of charcoal (Bird et al., 1999) or wood (Hatté et al., 2001) than the classical acid-base-acid (ABA) treatment. We used $4 \% \mathrm{HCl}\left(80^{\circ} \mathrm{C}, 1-2 \mathrm{~h}\right)$, followed by $0.5 \% \mathrm{NaOH}$ $\left(20^{\circ} \mathrm{C}, 1 \mathrm{~h}\right)$ followed by $2 \mathrm{M} \mathrm{H}_{2} \mathrm{SO}_{4}\left(80^{\circ} \mathrm{C}, 2 \mathrm{~h}\right)$ for the wet oxidation following Hatté et al. (2001) rather than the $\mathrm{K}_{2} \mathrm{Cr}_{4} \mathrm{O}_{7}$ used by Bird et al. (1999). A set of ABOX-treated samples of wood, twigs, mosses, and plant remains from Nesseltalgraben was compared with previously reported dates of similar material (Mayr et al., 2017) treated with the ABA method $(4 \% \mathrm{HCl}$, 2-3 h; 2\% NaOH, 1-2 h; 4\% $\mathrm{HCl}, 2-3 \mathrm{~h}$, all at $60^{\circ} \mathrm{C}$ ). The comparison between conventional ${ }^{14} \mathrm{C}$ ages of samples with $\mathrm{ABA}$ and $\mathrm{ABOX}$ pre-treatments showed increasing offsets ( $\triangle$ age $)$ with increasing age (Table 1). The comparatively young sample NE-6, originally dated to $27{ }^{14} \mathrm{C}$ ka BP, shows no statistically relevant offset after ABOX treatment. The same applies 
for the twig sample NE-7, but mosses from the same layer exhibited an $870{ }^{14} \mathrm{C}$ years older age than the twigs. In contrast, the ABOX treated samples NE-4, NE-5, and NE-2 were around 960, 4240, and $6940{ }^{14} \mathrm{C}$ years, respectively, older than the ABA-treated fractions (Table 1). In conclusion, the effects of contamination with younger carbon were especially critical for samples aged $40{ }^{14} \mathrm{C}$ ka BP or older and $\mathrm{ABOX}$ effectively removed those. In general the $\mathrm{ABA}$ method, while effective at removing humic acid contamination, may allow $\mathrm{CO}_{2}$ to link to the molecular structure of the sample and requires a strong acid to remove it (Hatté et al. 2001). The ABOX method (ABOX-2 in Hippe et al., 2018) we used might not be suitable for sample types such as peat which can contain components of different ages subject to differential degradation (Hippe et al. 2018) but was shown here to be more effective at contamination removal for our single entity samples than the ABA. Therefore, all further samples were pretreated with $\mathrm{ABOX}$ as described above.

The AMS ${ }^{14} \mathrm{C} /{ }^{12} \mathrm{C}$ ratio of each sample was background corrected and normalised to the HOXII standard (SRM 4990C; National Institute of Standards and Technology). The concurrently measured ${ }^{13} \mathrm{C} /{ }^{12} \mathrm{C}$ ratio was used for correcting for natural and analytical isotope fractionation. The fractionation corrected fraction modern carbon $\left(\mathrm{F}^{14} \mathrm{C}\right)$ was calculated as defined in Reimer et al. (2004). The radiocarbon age and one standard deviation was calculated using the Libby half-life following the method of Stuiver and Polach (1977). The IntCal13 (Reimer et al., 2013) curve and the Calib 7.1 software were used to calibrate ages. The age model was calculated using the software Bacon (Blaauw and Christen, 2011) using all default settings except for adapting the section thickness to $25 \mathrm{~cm}$ (the default of $5 \mathrm{~cm}$ would have resulted in too many sections to run the age-model).

\subsection{SEM-EDX elemental mapping}

For clarification of the origin of carbonate-rich layers, selected samples were embedded in epoxy resin (Gießharz Wasserklar), cut with a precision saw, ground with 400 and $800 \mathrm{SiC}$ and coated with carbon. Geochemical analysis was conducted on a Vega TESCAN $\backslash \backslash X M U$ scanning electron microscope (SEM). A silicon drift detector (X-MAX $50 \mathrm{~mm}$, Oxford instruments) and INCA 4.15 software (Oxford Instruments) were used to create element maps with energydispersive X-ray spectroscopy on a scanning electron microscope (SEM-EDX). The individual distributions of $\mathrm{Mg}, \mathrm{Ca}$ and $\mathrm{Si}$ were measured and combined in a qualitative composite element map for every sample. Measurement parameters include $10 \mathrm{kV}$ acceleration voltage, $15 \mathrm{~mm}$ 
working distance, probe current 6 and $310 \mathrm{~nm}$ spot size. Every sample was measured for around 45 minutes.

Following SEM-EDX elemental mapping, polished sample surfaces were etched for $30 \mathrm{~s}$ with $0.1 \mathrm{~N} \mathrm{HCl}$, rinsed in distilled water and again carbon coated. Under the SEM in secondary electron mode the etching reliefs of grains from these samples were documented. Additionally, petrographic thin sections with blue-stained epoxy resin were prepared for analyses of grain size, grainshape, and for assessing the presence of intra-grain cements. Dry bulk sediment from SEM samples was ground with a planet mill and investigated with X-ray diffraction (XRD) for mineral phases using Riethveld quantification.

\subsection{Carbon, nitrogen, and sulphur analyses}

An aliquot of about $1 \mathrm{ml}$ of selected samples, equally distributed over the profile, was homogenised with a mortar for determination of total carbon (TC), total inorganic carbon (TIC), total organic carbon (TOC), total nitrogen (TN), and total sulphur (TS). For TIC, TN, and TS about 10-50 mg of sample, depending on organic matter estimations based on a previous study (Mayr et al., 2017), were weighed together with $18 \mathrm{mg} \mathrm{V}_{2} \mathrm{O}_{5}$ in tin capsules and afterwards analysed with an elemental analyser (Euro EA, Eurovector, Germany). For TOC, about 10$20 \mathrm{mg}$ were weighed into silver capsules and afterwards decalcified in two steps first with 3\% $\mathrm{HCl}$ and subsequently with $20 \% \mathrm{HCl}$ on a heating device at $80{ }^{\circ} \mathrm{C}$ until effervescence stopped. The decalcified sample was then analysed with the same device. The TIC content was calculated from the difference between the TC and the TOC content. TIC contents were multiplied with a constant factor of 8.33 for the calculation of calcium carbonate contents, based on the molar mass of $\mathrm{C}$ relative to $\mathrm{CaCO}_{3}$ assuming a predominance of calcium carbonate (Zolitschka, 1998). Organic matter contents were calculated from TOC contents using a factor of 2.13 (Dean, 1974).

\subsection{Grain-size analyses}

For grain size analyses, between 0.3 and $1.0 \mathrm{~g}$ of each selected sample was sieved through a 2$\mathrm{mm}$ sieve and the sieved fraction dispersed with $30 \% \mathrm{H}_{2} \mathrm{O}_{2}$ to remove organic matter. Thereafter the sample was completely dispersed with $\left(\mathrm{NaPO}_{3}\right)_{\mathrm{n}}$. The grain-size distribution in suspension was analysed with a laser diffractometer (Beckman-Coulter LS 200). Triplicate measurements were performed for each sample for which the mean value is reported. 
Classification of the different grain-size fractions followed DIN EN ISO 14688-2:2018-05. Grain sizes $>2 \mathrm{~mm}$ were not quantified with this method.

\section{Results}

\subsection{Composite profile}

The composite profile covers $2099 \mathrm{~cm}$ cd in total (Fig. 3). It is overlain by glacifluvial gravel and lodgement till deposits. The boundary between exclusively glacifluvial and the uppermost lacustrine layer (Fig. 2 C) represents the $0 \mathrm{~cm}$ cd level. The top of the composite profile is at $582.03 \mathrm{~m}$ a.s.1., the bottom at $560.16 \mathrm{~m}$ a.s.1. resulting in a profile height of $2187 \mathrm{~cm}$ derived from geodetic measurements. Thus, the profile height from geodetic measurements appears to be $88 \mathrm{~cm}$ larger than the height of the composite profile obtained from the profile compilation. The main reason for this discrepancy is the compilation of the composite profile from outcrop sections up to $50 \mathrm{~m}$ apart (Sections B, C, D in Mayr et al., 2017) and the gentle dip of the strata towards the west with an angle between $0^{\circ}$ and $4^{\circ}$ over this distance. The discrepancy has no influence on the age model which was calculated using composite profile depths.

\subsection{Inorganic geochemistry}

Visually, the composite record shows large lithological variance predominantly caused by varying contents of carbonate and organic matter. In a first approach, the carbonate content was determined using XRF scanning data. The results indicate that $\mathrm{Ca}$ is antagonistic to all other elements occurring in significant amounts (Fig. 4). Ca comprises 9.9-98.7\% of total counts. Principal component analyses (PCA) on the correlation matrix, i.e. the z-transformed (studentised) XRF scanning data, resulted in $70 \%$ variance represented by the first principal component (PC1) and $8.8 \%$ by the second (PC2). The first principal component separated $\mathrm{Ca}$ from all other elements, the second groups $\mathrm{S}$ and $\mathrm{Zn}$ against all others. $\mathrm{Zn}$ and $\mathrm{S}$ show some accentuated peaks connected to high TOC contents. The broken-stick method revealed that only PC1 is statistically significant. Therefore, the scores of PC1 agree to a very high extent with $\mathrm{Ca}$ variations and inversely with most of the other elements except for S and $\mathrm{Zn}$ (Fig. 4).

Grain size varies largely in accordance with elemental composition, but there is a shift observable in the sign of correlation. Maxima of fine-grained (clay, fine silt) sediments go along 
with Ca maxima in the lower $75 \%$ of the profile $(570-2099 \mathrm{~cm} \mathrm{~cd})$. Above $570 \mathrm{~cm} \mathrm{~cd}$, however, the correlation pattern changes. Clay-rich levels in this segment are concurrent with $\mathrm{Ca}$ decreases whereas sandy intercalations represent the most Ca-rich layers (Fig. 4). ED-XRF data included more elements than XRF scanning. PCA results of the standardised EDXRF data are shown in Fig. 5. Similar as in the XRF scanning dataset, only PC 1 is significant as determined with the broken stick method and comprises $65.3 \%$ of the total variance. The elements $\mathrm{Ca}$ and $\mathrm{Mg}$ as well as LOI form a group with negative loadings on the first axis, while all other elements, including $\mathrm{K}, \mathrm{Ti}, \mathrm{Na}, \mathrm{P}, \mathrm{Mn}, \mathrm{Fe}, \mathrm{Sr}, \mathrm{Rb}, \mathrm{Zn}$, and $\mathrm{Zr}$ have positive loadings. Among the rock samples, various limestones and dolostones, belonging to different Mesozoic formations, also exhibit negative loadings, while rocks of the Permo-Triassic Werfen and Haselgebirge Fms. have positive loadings (Fig. 5). The Pleistocene sediments are spread over the whole scale range of PC1. PC1 predominantly separates carbonate-rich from carbonatepoor samples. PC2 is mainly influenced by a sample of manganese slate (A-2) contrasting to Mn-poor, but K- and Na-rich samples from the Haselgebirge. PC2, however, explains only $7.6 \%$ of the variance and therefore is not relevant for our interpretation.

\subsection{Composition and texture of carbonate layers}

The microscopic texture and chemical composition of carbonate layers was further investigated with SEM and elemental-mapping techniques. Samples were taken from six representative carbonate-rich layers between 78 and $1712 \mathrm{~cm} \mathrm{~cd}$. SEM analyses revealed no indications of endogenic or biogenic carbonate precipitation. All investigated carbonate layers are entirely of clastic origin. Petrographic thin sections showed a high porosity and loose packing of angular grains with no diagenetic cements in between. The SEM images of polished slabs exhibit subangular to angular grains of less than $100 \mu \mathrm{m}$ in size, a grain-supported texture, and poor sorting. Elemental mapping allows distinguishing three major grain components: $\mathrm{Mg}$-rich, Carich, and Si-rich grains (indicated by different colours in Fig. 6) in a fine-grained carbonate matrix. All evidences point to rock flour from the surrounding calcareous mountains as a primary source for the carbonate layers in the Nesseltalgraben section. Grain etching reliefs showed strong dissolution of Ca-rich grains, weak dissolution for Mg-rich grains and no dissolution for Si-rich grains pointing to limestone, dolostone, and quartz or silicate, respectively. Bulk XRD spectra confirmed calcite as main component, and dolomite and quartz as accessory components of the carbonate layers. 
Organic-matter rich layers (> 1\% TOC) occur at depths of 2093-1743, 1697-1630, 1560-1513, 1480-1466, 1276-1182, 1160-990, 953-471 (several peaks), and at $109 \mathrm{~cm} \mathrm{~cd}$. TOC and TN reach maximum values of 27.2 and $1.4 \mathrm{wt} \%$, respectively, at $1020 \mathrm{~cm} \mathrm{~cd}$. TS shows similar variations as TOC and TN, with a few additional maxima at 1350-1323 and 455-261 cm cd and at the base of the profile (2094 cm cd) in the uppermost part of the basal diamicton (Fig. 7). Organic layers coincide with layers enriched in $\mathrm{Ti}, \mathrm{K}$ and other elements, but are negatively correlated with carbonate-rich layers in which TOC and TN were frequently below detection level.

A comparison between XRF scanning data and elemental analyses shows consistency between data obtained with both techniques. In particular, the TS record is congruent with the sulphur record obtained from XRF scanning (Fig. 7). The sulphur record from XRF scanning shows enriched values in the basal diamicton (2091 to $2097 \mathrm{~cm} \mathrm{~cd}$ ) and where peaks in TS occur. TIC and $\mathrm{Ca}$ curves also show the same variability and differ only slightly, e.g. in baseline values. The strong coherence between TIC and Ca demonstrates that most of the $\mathrm{Ca}$ in the profile is bound to calcium carbonate and only a small fraction to other minerals such as silicates or sulphates (Fig. 7). Therefore, the Ca record can also be seen as representative for the carbonate content.

\subsection{Lithofacies}

Based on visual parameters (colour, bedding), grain size, TOC (representing organic matter content), and TIC (representing carbonate content) (Fig. 8), the composite profile was subdivided into six different lithofacies types (Fig. 7).

Lithotype A comprises gravel and sand layers with median grain sizes $>63 \mu \mathrm{m}$. Layers attributed to this lithofacies are of (glaci-)fluvial origin and between several $\mathrm{cm}$ and a few $\mathrm{dm}$ thick, have high carbonate $(55-95 \%)$ and low organic matter $(<0.5 \%)$ contents. They predominantly occur above $840 \mathrm{~cm} \mathrm{~cd}$ and appear with increasing frequency towards the top of the profile. Components in these layers predominantly are from Mesozoic carbonate rocks. Lithotype B is characterised by over-consolidated whitish to pale grey/ochre calcareous silt layers. Sediments of this lithofacies are frequently laminated and contain $<0.5 \%$ organic matter and $>50 \%$ carbonate. Thick layers of this lithotype occur in the lower half of the composite record, the most prominent between $1293-1464 \mathrm{~cm} \mathrm{~cd}$. Organic remains are very rare in this 
lithotype. Within thick lithotype-B layers or at their boundaries soft-sediment-deformation structures such as load casts, water-escape structures and flame-like structures frequently occur. Moreover, intercalated gravel bands, sand layers, and up to a few dm wide erosional channels were observed. The tops frequently have a reworked appearance e.g. at $1293 \mathrm{~cm} \mathrm{~cd}$ and $1704 \mathrm{~cm} \mathrm{~cd}$.

Lithotype C consists of light to medium grey/ochre silts with $0.5-5 \%$ organic matter content. It occurs as up to $1.5 \mathrm{~m}$ thick layers in the lower half. The layers can be laminated or unstratified. Towards the top of the profile, layers of lithotype $\mathrm{C}$ become thinner and rarer.

Lithotype D classifies medium to dark grey/brown silt layers with $5-10 \%$ organic matter content and $<50 \%$ carbonate content. Plant (charophyte stems, bryophyte shoots, angiosperm leaves, wood fragments) and animal remains (ostracod valves, gastropod and bivalve shells, chironomid head capsules, beetles, vertebrate bones) have been found predominantly in this lithotype.

Lithotype E signifies highly organic ( $>10 \%$ organic matter), dark-brown compressed silty peat or gyttia layers. The thickest layer of this lithotype occurs at $993-1033 \mathrm{~cm} \mathrm{~cd}$ and exhibits up to $58 \%$ organic matter content. At places, bryophyte and beetle remains are discernible macroscopically in this very dense lithotype.

Lithotype F classifies diamicton layers, i.e. unsorted or chaotically structured layers with a wide variety of grain sizes including pebbles or even boulders. Sediments of lithotype F occur only at the base of the composite profile (Fig. 2 E) and at 1519-1548 cm cd. The basal diamicton layer is 0.4 to $0.7 \mathrm{~m}$ thick, has irregular upper and lower boundaries and consists of angular to rounded, unsorted, grain-supported clastic components of sub-mm to several dm size. The clasts consist mainly of Mesozoic limestones and dolostones and to a minor extent of Cretaceous sandstones and very rarely metamorphic rocks in a dark-grey, silty matrix containing organic matter. Only the uppermost $8 \mathrm{~cm}$ (2091 to $2099 \mathrm{~cm} \mathrm{~cd})$ of the basal diamicton are included in the composite profile. The second layer attributed to lithofacies F $(1519-1548 \mathrm{~cm} \mathrm{~cd})$ contains unsorted carbonate clasts of up to several $\mathrm{cm}$ size in a silty matrix. This layer is probably laterally connected to a thick diamicton layer in an outcrop further to the east of the composite profile (section A in Mayr et al., 2017), which was previously tentatively correlated with the basal diamicton.

\subsection{Chronostratigraphy}


31 samples pre-treated with $\mathrm{ABOX}$ from the new sediment profile were radiocarbon dated (Table 2). The dated material consists of monocots leaves $(\mathrm{N}=8)$, macrophyte debris $(\mathrm{N}=4)$, bryophytes ( $\mathrm{N}=5)$, or wood (twigs, stems, or wood particles, $\mathrm{N}=14$ ) and covers almost the entire stratigraphic range. Except for a single sample (NTGRC-14) from the basal diamicton, which had no sufficient carbon for dating, all samples were datable and provided ages between 26,130 $\pm 230{ }^{14} \mathrm{C}$ yr BP (NTGRC-28) and 49,290 $\pm 5030{ }^{14} \mathrm{C}$ yr BP (NTGRC-9). For calculation of the age-depth model with Bacon, date NTGRC-32 had a too young age compared to adjacent samples and was discarded as outlier. The reason for the single erroneous age remains unclear, but most likely is related to contamination with traces of younger organic matter.

A Bacon age model (Fig. 9) was constructed using the remaining 30 radiocarbon dates. The age model revealed no major hiatuses, at least in the upper $1462 \mathrm{~cm}$ of the composite profile for which radiocarbon ages were entirely within the calibration curve. A previously reported paleomagnetic excursion (Mayr et al., 2017) was used as additional time marker for the age model. The new radiocarbon dates of this study confirm the earlier assignment of this paleomagnetic anomaly to the Laschamp event (41.3 $\pm 0.6 \mathrm{ka} \mathrm{BP}$; Laj et al., 2014). Ages below $1462 \mathrm{~cm}$ are at the limit of the radiocarbon calibration curve (50 ka cal BP). Thus, the model has a larger error in the lower part of the profile and the age-depth model effectively extrapolates beyond the lowermost dates using the sedimentation rates modelled further up the core. These extrapolated ages should be taken with caution. According to the age model, the top of the profile is dated to $29.6 \mathrm{ka}$ cal BP, and the lowermost sample has an extrapolated age of c. $59 \mathrm{ka}$ cal BP.

\section{Discussion}

\subsection{Paleoclimatic interpretation}

Selected proxy records $(\mathrm{Rb} / \mathrm{Sr}$ ratios, TOC, PC1 scores of XRF scanning data) from the Nesseltalgraben sediment sequence show large similarities. The variability resembles stadial and interstadial conditions as reflected in oxygen isotope records of Alpine speleothems and Greenland ice cores (Fig. 10). Sedimentary facies and geochemical signatures considered typical for warmer or cooler periods during MIS 3 are discussed in the following.

As a representative of organic matter content, TOC accumulated especially during deposition of lithotypes D and E. Compressed peat layers and humic horizons occur in various glacial 
deposits from the northern Alpine foreland. In a paleoclimatic context, such organic-rich layers in glacial sediments are commonly used as indicators of interstadial or interglacial conditions (Wohlfarth et al., 2008; Heiri et al., 2014). In the West Eifel Volcanic Field (Germany), the carbon contents of the Auel dry maar were used as a paleoclimatic proxy and for tuning the timescale to the Greenland ice-core chronology (Sirocko et al., 2016). In the Nesseltalgraben record, TOC contents of up to $27 \%$ (i.e. $58 \%$ organic matter) testify repeated periods of ameliorated climatic conditions favourable for higher bioproductivity, i.e. organic matter production in fen and lacustrine environments.

Almost all of the TOC peaks compare well with negative PC1 scores indicating enrichment of elements such as $\mathrm{K}, \mathrm{Si}, \mathrm{Ti}, \mathrm{Rb}, \mathrm{Sr}, \mathrm{Zr}$, and others. Si, apart from being component of siliceous microfossils such as diatom frustules (Kylander et al., 2011), is the major constituent of weathering-resistant minerals such as quartz and various silicates. Ti is frequently bound to very weathering-resistant minerals like titanium oxides and ilmenite (Correns, 1978). Zr occurs predominantly in zircon, which is also considered comparatively resistant to chemical weathering (Erlank et al. 1978). Moreover, Ti and Zr frequently accumulate in detrital and residual minerals of silt and sand fractions of soils and sediments (Milnes and Fitzpatrick, 1989, Boës et al., 2011; Kylander et al., 2011; Davies et al., 2015). Rb behaves similar like K. Both elements are constituents of mica and feldspar, but also accumulate in clay minerals via cation exchange (Brouwer et al., 1983). In the course of chemical weathering, the concentration of both elements generally increases due to adsorption to clay minerals (Heier and Billings, 1970; Liu et al., 1993; Buggle et al., 2011) if weathering is not too intense (Gallet et al., 1996; Buggle et al., 2011). Sr and $\mathrm{Ca}$ also show similar geochemical behaviour. Sr is a constituent of Kfeldspars and plagioclases and can substitute $\mathrm{Ca}$ in carbonates and sulfates (Veizer, 1970). Interestingly, Sr was most abundant in two of our rock samples from the Haselgebirge Fm. In contrast to $\mathrm{Rb}, \mathrm{Sr}$ is easily mobilised from parent rocks making the $\mathrm{Rb} / \mathrm{Sr}$ ratio a sediment proxy for chemical weathering (Dasch, 1969; Chen et al., 1999; Fernandez et al., 2013). Elevated $\mathrm{Rb} / \mathrm{Sr}$ ratios signify relative $\mathrm{Sr}$ loss through more intense chemical weathering and are in line with increased (logarithmised) TOC concentrations in our record (Fig. 10). Consequently, high $\mathrm{Rb} / \mathrm{Sr}$ ratios, increased TOC and negative PC1 scores all point to interstadial conditions when chemical weathering and bioproductivity was enhanced.

In contrast to the element $\mathrm{Sr}$, the easily soluble $\mathrm{Ca}$ was dominantly accumulated in the finegrained fractions of carbonate layers (lithotype B) in the Nesseltalgraben record. In these layers $\mathrm{Rb} / \mathrm{Sr}$ ratios and TOC values were low and scores of PC1 were high (Fig. 10). Grain-size and SEM-EDX analyses reveal that carbonates occur as clay-sized matrix as well as predominantly 
silt-sized components therein. This is a characteristic feature of rock flour originating from glacigenic grinding and, thus, a strong indication for glaciation (Harland et al., 1966; Small, 1987). Carbonate layers consist predominantly of angular calcite and dolomite grains with a small fraction of quartz, as evidenced from XRD, grain etching reliefs, and SEM-EDX elemental composition. Lithotype B resembles (late) glacial rock-flour deposits locally known as "mountain chalk" ("Bergkreide") elsewhere in the Northern Calcareous Alps (Jerz and Ulrich, 1966). Such deposits were typically formed by washout of fine clastic material from tills by glacigenic meltwater during the Late Pleistocene (Jerz 1993; Mair et al., 2016). The recognition of similar layers in the Nesseltalgraben record indicates the presence of glaciers with their meltwater in the Berchtesgaden basin during MIS 3. Repeated deposition of rock flour was also used for reconstructing glacier variability outside of the Alps, e.g. at Owens Lake (Sierra Nevada, USA) for the period between 79 and 15 ka BP (Bischoff and Cummins, 2001). Evidence for Middle Würmian glaciations in the northern Alps is extremely scarce. A possible glacier advance in the Kempten basin was dated to MIS 4 using luminescence methods (Link and Preusser, 2005). An ice-rafted-debris layer in the Baumkirchen record indicates the proximity of a local glacier around 60 to $55 \mathrm{ka} \mathrm{BP}$ in the Inn valley (Barrett et al., 2017a). Modelling results suggest that glaciers also repeatedly advanced and retreated during MIS 3 (Seguinot et al., 2018). Local glacier advances for that period, as indicated by the rock flour layers around 51.8-50.9, 49.7-48.7, and 46.3-42.9 cal ka BP in the Nesseltalgraben record, were, to the best of our knowledge, not yet reported from any other Alpine site.

From these considerations we reason that the layers characterised by lithotypes D and E, revealing high $\mathrm{Rb} / \mathrm{Sr}$ ratios and enriched in $\mathrm{TOC}, \mathrm{K}, \mathrm{Si}, \mathrm{Ti}, \mathrm{Rb}, \mathrm{Sr}$, and $\mathrm{Zr}$, represent interstadial, while Ca-rich and TOC-poor layers of lithotypes A and B represent stadial conditions. Lithotype $\mathrm{C}$ has an intermediate composition and thus represents a transitional facies between interstadial and stadial conditions.

Whether the deposition of two diamicton layers (lithotype F) was triggered by climatic shifts remains to be debated. We tentatively interpret them as debris flow deposits, which could be triggered by intensive thawing of the permafrost soil, as it has been observed in modern Arctic and periglacial environments (Matthews et al., 1999).

\subsection{Comparison with other regional records}

Several sites in the northern Alpine foreland provided humic horizons of Middle Würmian (i.e. MIS 3) age (Table 3). At the Swiss site Gossau, multiple-dating efforts provided age control for 
an interstadial complex consisting of humic horizons embedded in gravel and silty sand (Preusser et al., 2003). The three humic horizons of Gossau were dated to around $>50-49,42-$ 34, and $32{ }^{14} \mathrm{C}$ ka BP (Schlüchter et al. 1987), later confirmed by U/Th (Geyh and Schlüchter, 1998) and OSL dating (Preusser et al.. 2003).

The Niederweningen site in Switzerland provided humic horizons discovered during excavations and in drill cores (Furrer et al., 2007; Anselmetti et al., 2010). The middle and upper peat layers and fossils embedded therein have been dated to around $45-41{ }^{14} \mathrm{C} \mathrm{ka} \mathrm{BP}$ (Hajdas et al., 2007) supported by IRSL ages of $47 \pm 5 \mathrm{ka}$ and $44 \pm 4 \mathrm{ka}$ from underlying strata (Dehnert et al., 2012). The southern German site Breinetsried also provided radiocarbon dates from compressed peat layers of around 48 to $41{ }^{14} \mathrm{C}$ ka BP (Grootes, 1977, 1979; Peschke, 1983; Jerz, 1993).

Unterangerberg and Baumkirchen are inner-alpine sites located in the Inn valley which provided Middle Würmian strata. Luminescence and calibrated radiocarbon ages point to the existence of a lake during partly ameliorated climate conditions, indicated by organic-rich layers, at Unterangerberg around 55 to $45 \mathrm{ka}$ (Starnberger et al., 2013). At the adjacent locality Baumkirchen, lacustrine conditions of MIS 3 prevailed between 45 and $33 \mathrm{ka} \mathrm{cal} \mathrm{BP}$ (Barrett et al., 2017a). These sediments predominantly consist of finely laminated clays and silts and contain no humic horizons (Barrett et al., 2017a, b). However, pollen analyses revealed two milder periods between 41 to $37 \mathrm{ka}$ (PZ4) and around $35 \mathrm{ka}$ (PZ6) (Barrett et al., 2018).

Available Middle Würmian interstadial radiocarbon dates from these sites are compared with the Nesseltalgraben proxy records (Fig. 10). With the exception of Baumkirchen, for which the range given by the age model was used (Barrett et al., 2018), only dates within the range of radiocarbon calibration and with available error information were compiled and re-calibrated. Most of the interstadials discovered in the northern Alpine region match palynologically defined interstadials in the Netherlands and northern Germany, i.e. the Denekamp complex (Van der Hammen et al., 1967; Van der Hammen, 1971), Hengelo interstadial (Van der Hammen et al., 1967; Van der Hammen, 1971; Vandenberghe and van der Plicht, 2016), and the Moershoofd complex (Zagwijn, 1961; Van der Hammen, 1967; Van der Hammen, 1971; Teunissen and Teunissen-van Oorschrot, 1974). The oldest interstadials of Oerel and Glinde, attributed to MIS 3 by Behre and van der Plicht (1992), are not considered here, as they are clearly beyond the radiocarbon calibration range. The ages from the middle and upper peat layers at the Niederweningen excavation site (Hajdas et al., 2007) and from Gossau 1 (Schlüchter et al., 1987) cluster with the dates of the Moershoofd complex (Fig. 10). The welldated Hengelo interstadial is not present in any of the northern Alpine records, but is time- 
equivalent to interstadials we tentatively attribute to GI 10/11 in our record. The Denekamp complex, although controversially debated (Litt et al., 2007), seems to be equivalent to Gossau 3 and PZ6 from Baumkirchen and to maxima in the Nesseltalgraben record centred around GI 6.

While other regional sites provided a few humic horizons or compressed peat layers for the Middle Würmian, Nesseltalgraben revealed more than 20 short-term periods with increased TOC (>0.5 \%) contents. Only few loess and lacustrine sediment records (Sirocko et al., 2016; Moine et al., 2017; Duprat-Oualid et al., 2017) from Central Europe show similar DansgaardOeschger variability as in Greenland ice cores. A comparison between $\delta^{18} \mathrm{O}$ records from the North Greenland Ice Core Project (NGRIP, Rasmussen et al., 2014) and the Northern European Alps Stalagmite Chronology (NALPS) demonstrates strong linkages between Central European and Greenland paleoclimate variability during MIS 3 (Moseley et al., 2014; Fig. 10). Unfortunately, the NALPS $\delta^{18} \mathrm{O}$ record does not cover the complete MIS 3 because of intermittent speleothem growth interruptions (Moseley et al., 2014). Such growth interruptions were not observed in the Sieben Hengste cave system, but this record does not exceed $29.9 \mathrm{ka}$ BP (Luetscher et al., 2015). Provided that climatic changes in Greenland and Europe were synchronous, the plentiful interstadials found at Nesseltalgraben rather than the few reported from other northern (pre)Alpine sites document the regional climatic variability during MIS 3 (Fig. 10). Apparently, most Alpine sediment records of MIS 3 do not record the full pre-LGM climatic variability. In most cases, hiatuses are the most likely explanation for their fragmentary records. At the Nesseltalgraben site the origin and persistence of the sedimentary basin has been attributed to long-term subrosion of underlying Permotriassic evaporitic rocks (Mayr et al., 2017), which could explain such a long period of sediment deposition in an alpine setting. The sediments at Nesseltalgraben could represent remnants of a previously more widespread preLGM basin filling which was obliterated elsewhere in the Berchtesgaden valley by glacial erosion during the LGM.

The Nesseltalgraben record allows a comparison between a sediment record from the N-Alps with Greenland stadials and interstadials over the entire range of MIS 3. A tentative correlation reveals that several of the Greenland interstadials correlate with geochemical variability in the Nesseltalgraben record, in particular GI 6, 8, and 14-17. Multiple peaks characterise GI 5 and 7 in the Nesseltalgraben record, while GI 10 and 11 appear as double peaks in the PC1 record. The stadials separating GI 11 and 12 as well as GI 13 and 14 are longer, and a small cooling event during GI 14 appears more prominent in the Nesseltalgraben record compared to NGRIP. Owing to the chronological uncertainties of independently dated records, synchronicity 
between events cannot be established with ultimate certainty, as has been previously demonstrated by comparing the well-dated record of paleolake Les Echets with the Greenland ice core record (Blaauw et al., 2010). Moreover, response times may have been different among proxies and archives. While ice-core $\delta^{18} \mathrm{O}$ records reflect a direct and immediate proxy response to atmospheric changes (Thomas et al., 2007), sedimentary processes also depend on a variety of factors related to the catchment, such as geology, soil cover, vegetation, or geomorphology (Einsele and Hinderer, 1998). Glacigenic lithofacies B may have already been deposited when first cooling caused glacier advances during a fading GI and may have lasted until first warming occurred during the beginning next GI when enhanced meltwater still provided rock flour. This may explain that cool stadial phases in the older half of the record, in particular the one between GI 11 and 12, appear longer than in the NGRIP record. In general, all discussed differences between the records should be considered on the basis of dating uncertainties which are particularly large for the oldest part (>50 cal ka BP) of the Nesseltalgraben record based on extrapolation (Fig. 10 F).

\subsection{Implications for Middle Würmian stratigraphy}

The end of the Middle Würmian is defined by a facies change from lacustrine laminated clayey silts to glacifluvial deposits at the inner-alpine stratotype section Baumkirchen (Chaline and Jerz 1984). This sedimentary change also indicates the start of the LGM. Recent dating improvements pinpoint the start of the LGM to 33-32 cal ka BP at Baumkirchen (Spötl et al., 2014). In the southeastern Alps, glacifluvial activity started in the proximal parts of the outwash of the Tagliamento fan (Monegato et al., 2007) and in adjacent Cormor fan (Hippe et al., 2018) at around 32-31 cal ka BP, while in the distal parts of the Tagliamento fan the onset was dated to between 30.8-29.9 cal ka BP and 28.7-27.8 cal ka BP (Monegato et al., 2007). Further to the south in the Lake Fimon area, glacifluvial damming of a deeper lake due to aggradation of the Brenta River outwash fan dated to 27.5-27.2 cal ka BP (Monegato et al., 2011).

The onset of continuous glacifluvial sedimentation in the Nesseltalgraben record starts at 29.6 cal ka BP (modelled age). Thus the LGM phase started later than at Baumkirchen and at the proximal Tagliamento fan, but earlier than in the distal Tagliamento area and at Lake Fimon. However, thin gravel intercalations already occurred earlier in the record represented by lithotype A (Fig. 8). Therefore, the onset of the LGM probably was a more gradual process and strongly depended on local geomorphological and mesoclimatic conditions. This comparison also shows that local conditions such as accumulation areas of glaciers, successive overcoming 
of watersheds between glaciers and sedimentary basins, and spatially varying precipitation amounts played a larger role for the onset of the LGM as also suggested by modelling of Alpine glaciations during the Würmian (Seguinot et al., 2018).

\section{Conclusions}

In comparison to other regional records, the frequency of humic layers in the Nesseltalgraben is extraordinarily high. Due to its high-resolution age model it can serve as a key MIS 3 section in the northern Alps. The geochemical variations, in particular PC1 scores, $\mathrm{Rb} / \mathrm{Sr}$ ratios, and TOC contents, document a pronounced similarity with Dansgaard-Oeschger climate variability derived from Greenland ice cores and northern Alpine speleothems. Despite this overall similarity, not all GIs and GSs appear synchronous to peaks in the Nesseltalgraben proxy records owing to dating uncertainties and possibly different response times of the archives. Several glacier advances are indicated by calcareous clastic silt layers, in particular around 51.8-50.9, 49.7-48.7, and 46.3-42.9 cal ka BP, which have not yet been reported from anywhere else in the Alps. The onset of the LGM at the Nesseltalgraben site dates to $29.6 \mathrm{cal}$ $\mathrm{ka} \mathrm{BP}$ and is within the range of reported dates from other sites in Austria and northern Italy. Ongoing investigations at the Nesseltalgraben site, including palynological and isotopic analyses, will complement the presented geochemical studies and will shed further light on the environmental development during MIS 3 in the northern Alps.

\section{Acknowledgements}

We are much obliged for financial support of the investigations by the German Research Foundation (DFG) in the framework of the project ALPWÜRM (MA 4235/10-1). We thank Sabine Stahl, Theresa Stauber, Lukas Sochor, and Katrin Wagner for their assistance with grainsize and elemental analyses, and Melanie Hertel and Michael Grau for ED-XRF analyses. Michael Grau, Michael Weber, Arne Rickmeyer, Jonas Kiesel, Sebastian Koller, Martin Schommer, and Anita Vergin are acknowledged for their help during fieldwork and Peter Wasmeier for evaluating geodetic measurements. We are indebted to Josef März for drawing our attention to the site and for logistic help during the initial project phase. Ulrich Haas and Ulrich Teipel generously introduced CM to the regional geology, and Emilia Jarochowska, Axel 
640

641

642

643

644

645

646

647

648

649

650

651

652

653

654

655

656

657

658

659

660

661

662

663

664

665

666

667

668

669

670

671

672

Munnecke, and Christian Schulbert provided resources for EDX elemental mapping. Najat alFudhaili and Abdelrahman Abdelshafv helped with carbonate sample preparation. This is ISMAR publication no. 2002. We are grateful to Christoph Spötl and an anonymous reviewer for helpful comments on an earlier version of the manuscript.

\section{References}

Anselmetti, F., Drescher-Schneider, R., Furrer, H., Graf, H.R., Lowick, S.E., Preusser, F., Riedi, M.A., 2010. A $\sim 180,000$ years sedimentation history of a perialpine overdeepened glacial trough (Wehntal, N-Switzerland). Swiss Journal of Geosciences $103,345-361$.

Barrett, S., Starnberger, R., Tjallingii, R., Brauer, A., Spötl, C., 2017a. The sedimentary history of the inner-alpine Inn Valley, Austria: extending the Baumkirchen type section further back in time with new drilling. Journal of Quaternary Science 32, 63-79.

Barrett, S., Schmidmair, D., Spötl, C., 2017b. Mineralogical composition of the Baumkirchen lacustrine sequence (Würmian, Inn Valley, Tyrol): provenance and paleogeographical implications. Austrian Journal of Earth Sciences 110, 43-56.

Barrett, S.J., Drescher-Schneider, R., Starnberger, R., Spötl, C., 2018. Evaluation of the regional vegetation and climate in the Eastern Alps (Austria) during MIS 3-4 based on pollen analysis of the classical Baumkirchen paleolake sequence. Quaternary Research 90, 153-163.

Behre, K.-E., van der Plicht, J., 1992. Towards an absolute chronology Europe: radiocarbon dates from for the last glacial period in Oerel, northern Germany. Vegetation History and Archaeobotany 1, 111-117.

Bird, M.I., Ayliffe, L.K., Fifield, L.K., Turney, C.S.M., Cresswell, R.G., Barrows, T.T., David, B., 1999. Radiocarbon dating of "old" charcoal using a wet oxidation, steppedcombustion procedure. Radiocarbon 41, 127-140.

Bischoff, J.L., Cummins, K., 2001. Wisconsin Glaciation of the Sierra Nevada (79,000-15,000 yr B.P.) as recorded by rock flour in sediments of Owens Lake, California. Quaternary Research 55, 14-24.

Blaauw, M., Wohlfarth, B., Christen, J.A., Ampel, L., Veres, D., Hughen, K.A., Preusser, F., Svensson, A., 2010. Were last glacial climate events simultaneous between Greenland 
and France? A quantitative comparison using non-tuned chronologies. Journal of Quaternary Science 25, 387-394.

Blaauw, M., Christen, J.A., 2011. Flexible paleoclimate age-depth models using an autoregressive gamma process. Bayesian Analysis 6, 457-474.

Blockley, S.P.E., Bourne, A.J., Brauer, A., Davies, S.M., Hardiman, M., Harding, P.R., Lane, C.S., MacLeod, A., Matthews, I.P., Pyne-O’Donnell, D.F., Rasmussen, S.O., Wulf, S., Zanchetta, G., 2014. Tephrochronology and the extended intimate (integration of icecore, marine and terrestrial records) event stratigraphy 8-128 ka b2k. Quaternary Science Reviews 106, 88-100.

Boës, X., Rydberg, J., Martinez-Cortizas, A., Bindler, R., Renberg, I., 2011. Evaluation of conservative lithogenic elements $(\mathrm{Ti}, \mathrm{Zr}, \mathrm{Al}$, and $\mathrm{Rb}$ ) to study anthropogenic element enrichments in lake sediments. Journal of Paleolimnology 46, 75-87.

Brouwer, E., Baeyens, B., Maes, A., Cremers, A., 1983. Cesium and rubidium ion equilibria in illite clay. Journal of Physical Chemistry 87, 1213-1219.

Buggle, B., Glaser, B., Hambach, U., Gerasimenko, N., Marković, S., 2011. An evaluation of geochemical weathering indices in loess-paleosol studies. Quaternary International $240,12-21$.

Burga, C.A., 2006. Zum Mittelwürm des Zürcher Oberlandes am Beispiel des SchieferkohleProfils von Gossau (Kanton Zürich). Vierteljahrsschrift der Naturforschenden Gesellschaft in Zürich 151, 91-100.

Chaline, J., Jerz, H., 1984. Arbeitsergebnisse der Subkommission für Europäische Quartärstratigraphie. Stratotypen des Würm-Glazials. Eiszeitalter und Gegenwart 35, 185-206.

Chen, J., An, Z., Head, J., 1999. Variation of Rb/Sr ratios in the loess-paleosol sequences of Central china during the last 130,000 years and their implications for monsoon paleoclimatology. Quaternary Research 51, 215-219.

Correns, C.W., 1978. Titanium. Behavior during weathering and rock alteration. In: Wedepohl, K.H. (Ed.), Handbook of Geochemistry Vol II/2, Springer, Berlin, Heidelberg New York, 22-G-1-3.

Dasch, E.J., 1969. Strontium isotopes in weathering profiles, deep-sea sediments, and sedimentary rocks. Geochimica et Cosmochimica Acta 33, 1521-1552.

Davies, S.J., Lamb, H., Roberts, S.J., 2015. Micro-XRF Core Scanning in Palaeolimnology: Recent Developments. In: Croudace, I.W., Rothwell, G. (Eds.), Micro-XRF Studies of Sediment Cores, Springer, Dordrecht, pp. 189-226. 
Dean, W.E., 1974. Determination of carbonate and organic matter in calcareous sediments and sedimentary rocks by loss on ignition: comparison with other methods. Journal of Sedimentary Petrology 44, 242-248.

Dehnert, A., Lowick, S.E., Preusser, F., Anselmetti, F.A., Drescher-Schneider, R., Graf, H.R., Heller, F., Horstmeyer, H., Kemna, H.A., Nowaczyk, N., Züger, A., Furrer, H., 2012. Evolution of an overdeepened trough in the northern Alpine Foreland at Niederweningen, Switzerland. Quaternary Science Reviews 34, 127-145.

Duprat-Oualid, F., Rius, D., Bégeot, C., Magny, M., Millet, L., Wulf, S., Appelt, O., 2017. Vegetation response to abrupt climate changes in Western Europe from 45 to $14.7 \mathrm{k}$ cal a BP: the Bergsee lacustrine record (Black Forest, Germany). Journal of Quaternary Science 32, 1008-1021.

Einsele, G., Hinderer, M., 1998. Quantifying denudation and sediment-accumulation systems (open and closed lakes): basic concepts and first results. Palaeogeography, Palaeoclimatology, Palaeoecology 140, 7-21.

Erlank, A.J., Smith, H.S., Marchant, J.W., Cardoso, M.P., Ahrens, L.H., 1978. Zirconium. Behavior during weathering and alteration of rocks. In: Wedepohl, K.H. (Ed.), Handbook of Geochemistry Vol II/4, Springer, Berlin, Heidelberg New York, 40-G-15.

Fernández, M., Björck, S., Wohlfarth, B., Maidana, N.I., Unkel, I., Van der Putten, N., 2013. Diatom assemblage changes in lacustrine sediments from Isla de los Estados, southernmost South America, in response to shifts in the southwesterly wind belt during the last deglaciation. Journal of Paleolimnology 50, 433-446.

Fischer, K., 1988. Die würmzeitliche und stadiale Vergletscherung der Berchtesgadener Alpen. Berliner Geographische Abhandlungen 47, 207-225.

Furrer, H., Graf, H.R., Mäder, A., 2007. The mammoth site of Niederweningen, Switzerland. Quaternary International 164-165, 85-97.

Gallet, S., Jahn, B.-M., Torii, M., 1996. Geochemical characterization of the Luochuan loesspaleosol sequence, China, and paleoclimatic implications. Chemical Geology 133, 67-88.

Geologische Bundesanstalt Wien, 2005. Geologische Karte von Salzburg 1:200 000.

Geyh, M.A., Schlüchter, C., 1998. Calibration of the ${ }^{14} \mathrm{C}$ time scale beyond 22,000 BP. Radiocarbon 40, 475-482.

Grootes, P.M., 1977. Thermal diffusion isotopic enrichment and radiocarbon dating beyond 50000 years BP. Dissertation, University of Groningen: 221 pp. 
Grootes, P.M., 1979. Kohlenstoff-14 Anreicherungsdatierungen im Alpenvorland. Geologica Bavarica 80, 183-188.

Hajdas, I. Bonani, G., Furrer, H., Mäder, A. Schoch, W., 2007. Radiocarbon chronology of the mammoth site at Niederweningen, Switzerland: Results from dating bones, teeth, wood, and peat. Quaternary International 164-165, 98-105.

Hammer, Ø., Harper, D.A.T., Ryan, P.D., 2001. PAST: Paleontological statistics software package for education and data analysis. Palaeontologia Electronica 4(1): 9 pp.

Harland, W.B., Herod, K.N., Krinsley, D.H., 1966. The definition and identification of tills and tillites. Earth-Science Reviews 2, 225-256.

Hatté, C., Morvan, J., Noury, C., Paterne, M., 2001. Is classical acid-alkali-acid treatment responsible for contamination? An alternative proposition. Radiocarbon 43, 177-82.

Heier, K.S., Billings, G.K., 1970.Rubidium. Behavior during weathering and abundance in soils. In: Wedepohl, K.H. (Ed.), Handbook of Geochemistry Vol II/4, Springer, Berlin, Heidelberg New York, 37-G1-2.

Heiri, O., Koinig, K.A., Spötl, C., Barrett, S., Brauer, A., Drescher-Schneider, R., Gaar, D., Ivy-Ochs, S., Kerschner, H., Luetscher, M., Moran, A., Nicolussi, K., Preusser, F., Schmidt, R., Schoeneich, P., Schwörer, C., Sprafke, T., Terhorst, B., Tinner, W., 2014. Palaeoclimate records 60-8 $\mathrm{ka}$ in the Austrian and Swiss Alps and their forelands. Quaternary Science Reviews 106, 186-205.

Hippe, K., Fontana, A., Hajdas, I., Ivy-Ochs, S., 2018. A high-resolution ${ }^{14} \mathrm{C}$ chronology tracks pulse of aggradation of glaciofluvial sediment on the Cormor megafan between 45 and 20 ka BP. Radiocarbon 60, 857-874.

Ivy-Ochs, S., Kerschner, H., Reuther, A., Preusser, F., Heine, K., Maisch, M., Kubik, P., Schlüchter, C., 2008. Chronology of the last glacial cycle in the European Alps. Journal of Quaternary Science 23, 559-573.

Jerz, H., 1993. Geologie von Bayern II. Das Eiszeitalter in Bayern. Schweizerbart, Stuttgart: $243 \mathrm{pp}$.

Jerz, H., Ulrich, R., 1966. Erläuterungen zur geologischen Karte von Bayern 1:25000, Blatt Nr. 8533/8633 Mittenwald. Bayerisches Geologisches Landesamt, München: 152 pp.

Kellerbauer, S., 1996. Geologie und Geomechanik der Salzlagerstätte Berchtesgaden. Münchner Geologische Hefte B2 2: 101 pp.

Kylander, M.E., Ampel, 1., Wohlfarth, B., Veres, D., 2011. High-resolution X-ray fluorescence core scanning analysis of Les Echets (France) sedimentary sequence: new insights from chemical proxies. Journal of Quaternary Science 26, 109-117. 
Laj, C., Guillou, H., Kissel, C., 2014. Dynamics of the earth magnetic field in the 10-75 kyr period comprising the Laschamp and Mono Lake excursions: New results from the French Chaîne des Puys in a global perspective. Earth and Planetary Science Letters 387, 184-197.

Link, A., Preusser, F., 2005. Hinweise auf eine Vergletscherung des Kemptener Beckens (Südwest-Bayern) im Mittleren Würm. Eiszeitalter und Gegenwart 55, 64-87.

Lisiecki, L.E., Raymo, M.E., 2005. A Pliocene-Pleistocene stack of 57 globally distributed benthic $\delta^{18} \mathrm{O}$ records. Paleoceanography 20, PA1003, doi:10.1029/2004PA001071.

Litt, T., Behre, K.-E., Meyer, K.-D., Stephan, H.-J., Wansa, S., 2007. Stratigraphische Begriffe für das Quartär des norddeutschen Vereisungsgebietes. E\&G Quaternary Science Journal 56, 7-65.

Liu, C.-Q., Masuda, A., Okada, A., Yabuki, S., Zhang, J., Fan, Z.-L., 1993. A geochemical study of loess and desert sand in northern China: Implications for continental crust weathering and composition. Chemical Geology 106, 359-374.

Luetscher, M., Boch, R., Sodemann, H., Spötl, C., Cheng, H., Edwards, R.L., Frisia, S., Hof, F., Müller, W., 2015. North Atlantic storm track changes during the Last Glacial Maximum recorded by Alpine speleothems. Nature Communications 6:6344, doi: $10.1038 /$ ncomms 7344 .

Mair, D., Chwatal, W., Reimer, P.J., Spötl, C., 2016. Quaternary evolution of the inner Riss Valley, Tyrol (Austria) - an integrated sedimentological and geophysical case study. Austrian Journal of Earth Sciences 109, 277-288.

Matthews, J.A., Shakesby, R.A., McEwen, L.J., Berrisford, M.S., Owen, G., Bevan, P., 1999. Alpine debris-flows in Leirdalen, Jotunheimen, Norway, with particular reference to distal fans, intermediate-type deposits, and flow types. Arctic, Antarctic, and Alpine Research 31, 421-435.

Mayr, C., Brandlmeier, B., Diersche, V., Stojakowits, P., Kirscher, U., Matzke-Karasz, R., Bachtadse, V., Eigler, M., Haas, U., Lempe, B., Reimer, P.J., Spötl, C., 2017. Nesseltalgraben, a new reference section of the last glacial period in southern Germany. Journal of Paleolimnology 58, 213-229.

Milnes, A.R, Fitzpatrick, R.W., 1989. Titanium and Zirconium minerals. In: Bigham, J.M., Dixon, J.B.M., Milford, H., Roth, C.B., Weed, S.B. (Eds.), Minerals in Soil Environments, Soil Science Society of America, Madison, pp 1131-1205.

Moine, O., Antoine, P., Hatté, C., Landais, A., Mathieu, J., Prud'homme, C., Rousseau, D.-D., 2017. The impact of Last Glacial climate variability in west-European loess revealed by 
radiocarbon dating of fossil earthworm granules. Proceedings of the National Academy of Sciences of the United States of America, doi:10.1073/pnas.1614751114.

Monegato, G., Ravazzi, C., Donegana, M., Pini, R., Calderoni, G., Wick, L., 2007. Evidence of a two-fold glacial advance during the last glacial maximum in the Tagliamento end moraine system (eastern Alps). Quaternary Research 68, 284-302.

Monegato, G., Pini, R., Ravazzi, C., Reimer, P.J., Wick, L., 2011. Correlating Alpine glaciation with Adriatic sea-level changes through lake and alluvial stratigraphy. Journal of Quaternary Science 26, 791-804.

Moseley, G.E., Spötl, C., Svensson, A., Cheng, H., Brandstätter, S., Edwards, R.L., 2014. Multi-speleothem record reveals tightly coupled climate between central Europe and Greenland during Marine Isotope Stage 3. Geology 42, 1043-1046.

Müller, U.C., Pross, J., Bibus, E., 2003. Vegetation response to rapid climate change in Central Europe during the past 140,000 yr based on evidence from the Füramoos pollen record. Quaternary Research 59, 235-245.

Ohlendorf, C., 2018. A sample carrier for measuring discrete powdered samples with an ITRAX XRF core scanner. X-Ray Spectrometry 47, 58-62.

Peschke, P., 1983. Palynologische Untersuchungen interstadialer Schieferkohlen aus dem schwäbisch-oberbayerischen Alpenvorland. Geologica Bavarica 84, 69-99.

Pichler, H., 1963. Geologische Untersuchungen im Gebiet zwischen Rossfeld und Markt Schellenberg im Berchtesgadener Land. Beihefte Geologisches Jahrbuch 48, 129-204.

Pini, R., Ravazzi, C., Reimer, P.J., 2010. The vegetation and climate history of the last glacial cycle in a new pollen record from Lake Fimon (southern Alpine foreland, N-Italy). Quaternary Science Reviews 29, 3115-3137.

Preusser, F., Geyh, M.B., Schlüchter, C., 2003. Timing of Late Pleistocene climate change in lowland Switzerland. Quaternary Science Reviews 22, 1435-1445.

Rasmussen, S.O., Bigler, M., Blockley, S.P., Blunier, T., Buchardt, S.L., Clausen, H.B., Cvijanovic, I., Dahl-Jensen, D., Johnsen, S.J., Fischer, H., Gkinis, V., Guillevic, M., Hoek, W.Z., Lowe, J.J., Pedro, J.B., Popp, T., Seierstad, I.K., Steffensen, J.P., Svensson, A.M., Vallelonga, P., Vinther, B.M., Walker, M.J.C., Wheatley, J.J., Winstrup, M., 2014. A stratigraphic framework for abrupt climatic changes during the Last Glacial period based on three synchronized Greenland ice-core records: refining and extending the INTIMATE event stratigraphy. Quaternary Science Reviews 106, 14-28.

Reimer, P.J., Brown, T.A., Reimer, R.W., 2004. Discussion: Reporting and calibration of postbomb C-14 data. Radiocarbon 46, 1299-1304. 
Reimer, P.J., Bard, E., Bayliss, A., Beck, J.W., Blackwell, P.G., Bronk Ramsey, C., Buck, C.E., Cheng, H., Edwards, R.L., Friedrich, M., Grootes, P.M., Guilderson, T.P., Haflidason, H., Hajdas, I., Hatté, C., Heaton, T.J., Hoffmann, D.L., Hogg, A.G., Hughen, K.A., Kaiser, K.F., Kromer, B., Manning, S.W., Niu, M., Reimer, R.W., Richards, D.A., Scott, E.M., Southon, J.R., Staff, R.A., Turney, C.S.M., van der Plicht, J., 2013. IntCal13 and MARINE13 radiocarbon age calibration curves 0-50,000 years cal BP. Radiocarbon $55,1869-1887$.

Schlüchter, C., Maisch, M., Suter, J., Fitze, P., Keller, W.A., Burga, C.A., Wynistorf, E., 1987. Das Schieferkohlen-Profil von Gossau (Kanton Zürich) und seine stratigraphische Stellung innerhalb der letzten Eiszeit. Vierteljahrsschrift der Naturforschenden Gesellschaft in Zürich 132, 135-174.

Seguinot, J., Ivy-Ochs, A., Jouvet, G., Huss, G., Funk, M., Preusser, F., 2018. Modelling last glacial cycle ice dynamics in the Alps. The Cryosphere 12, 3265-3285.

Sirocko, F., Knapp, H., Dreher, F., Förster, M.W., Albert, J., Brunck, H., Veres, D., Diettrich, S., Zech, M., Hambach, U., Röhner, M., Rudert, S., Schwibus, K., Adams, C., Sigl, P., 2016. The ELSA-Vegetation-Stack: Reconstruction of Landscape Evolution Zones (LEZ) from laminated Eifel maar sediments of the last 60,000 years. Global and Planetary Change 142, 108-135.

Small, R.J., 1987. Moraine sediment budget. In: A. M. Gurnell, A.M., Clark, M.J. (Eds.) Glaciofluvial sediment transfer, 165-197.

Spötl, C., 1988. Sedimentologisch-fazielle Analyse tektonisierter Evaporitserien - eine Fallstudie am Beispiel des alpinen Haselgebirges (Permoskyth, Nördliche Kalkalpen). Geologisch-Paläontologische Mitteilungen Innsbruck 15, 59-69.

Spötl, C., Reimer, P.J., Starnberger, R., Reimer, R.W., 2014. A new radiocarbon chronology of Baumkirchen, stratotype for the onset of the Upper Würmian in the Alps. Journal of Quaternary Science 28, 552-558.

Spötl, C., Mangini, A., 2002. Stalagmite from the Austrian Alps reveals Dansgaard-Oeschger events during isotope stage 3: Implications for the absolute chronology of Greenland ice cores. Earth and Planetary Science Letters 203, 507-518.

Starnberger, R., Drescher-Schneider, R., Reitner, J.M., Rodnight, H., Reimer, P.J., Spötl, C., 2013. Late Pleistocene climate change and landscape dynamics in the Eastern Alps: the inner-alpine Unterangerberg record (Austria). Quaternary Science Reviews 68, 17-42.

Stuiver, M., Polach, H.A., 1977. Reporting of C-14 data - discussion. Radiocarbon 19, 355363. 
Teunissen, D., Teunissen-van Oorschot, H., 1974. Eine interstadiale Torfschicht bei Nijmegen (Niederlande) und deren Bedeutung für die Erklärung der dortigen Lanschaftsmorphologie. Geologie en Mijnbouw 53, 393-400.

Thomas, E.R., Wolff, E.W., Mulvaney, R., Steffensen, J.P., Johnsen, S.J., Arrowsmith, C., White, J.W.C., Vaughn, B., Popp, T., 2007. The 8.2 ka event from Greenland ice cores. Quaternary Science Reviews 26, 70-81.

Vandenberghe, J., van der Plicht, J., 2016. The age of the Hengelo interstadial revisited. Quaternary Geochronology 32, 21-28.

Van der Hammen, T., Maarleveld, G.C., Vogel, J.C., Zagwijn, W.H., 1967. Stratigraphy, climatic succession and radiocarbon dating of the Last Glacial in The Netherlands. Geologie en Mijnbouw 46, 79-95.

Van der Hammen, T., 1971. The Denekamp, Hengelo and Moershoofd interstadials. In: Van der Hammen, T., Wijmstra, T.A. (Eds.), The Upper Quaternary of the Dinkel Valley (Twente, Eastern Overijssel, The Netherlands). Mededelingen Rijks Geologische Dienst $22,81-85$.

Van Husen, D., 2000. Geological processes during the Quaternary. Mitteilungen der Österreichischen Geologischen Gesellschaft 92, 135-156.

Veizer, J., 1978. Strontium. Abundance in common sediments and sedimentary rock types. Handbook of Geochemistry Vol II/4, Springer, Berlin, Heidelberg New York, 38K1-13.

Wang, Y.J., Cheng, H., Edwards, R.L., An, Z.S., Wu, J.Y., Shen, C.-C., Dorale, J.A., 2001. A High-Resolution Absolute-Dated Late Pleistocene Monsoon Record from Hulu Cave, China. Science 294, 2345-2348.

Wohlfarth, B., Veres, D., Ampel, L., Lacourse, T., Blaauw, M., Preusser, F., Andrieu-Ponel, V., Lallier-Vergès, Björck, S., Davies, S.M., de Beaulieu, J.-L., Risberg, J., Hormes, A., Kasper, H.U., Possnert, G., Reille, M., Thouveny, N., Zander, A., 2008. Rapid ecosystem response to abrupt climate changes during the last glacial period in western Europe, 40-16 ka. Geology 36, 407-410.

Zagwijn WH, 1961. Vegetation, climate and radiocarbon datings in the late Pleistocene of the Netherlands, Part I: Eemian and Early Weichselian. Mededelingen van de Geologische Stichting NS 14, 15-45.

Zolitschka, B., 1998. A 14,000 year sediment yield record from western Germany based on annually laminated lake sediments. Geomorphology 22, 1-17. 
Fig. 1. Simplified geological map of the Berchtesgaden area (modified from Geologische Bundesanstalt Wien, 2005, geographic basic data from Bayerische Vermessungsverwaltung). The sampling sites of rock samples (white dots) and the Nesseltalgraben site (black dot) are indicated. The inserted map shows the position of the research area in southeastern Germany.

Fig. 2. Outcrop views from the Nesseltalgraben site. (A) Uppermost c. $9 \mathrm{~m} \mathrm{~cd}$ of the sampled sediment profile on the upper slope of Nesseltalgraben. Profile represents the upper part of section B in Mayr et al. (2017). (B) Lower part of the sediment profile (c. 13-21 m cd), view to the south. White boxes indicate the sampled areas corresponding to sections C (left) and D (right) in Mayr et al. (2017). (C) Detail of the uppermost sampled part showing the boundary between glacifluvial gravel and fine-grained, partly lacustrine deposits (white line). Field book $(19 \times 12 \mathrm{~cm})$ is for scale. The sampled part to the right of the folding rule corresponds to $0.0-1.1$ $\mathrm{m}$ cd. (D) Detail of the left section in (B) with the thick carbonate layer at 12.9-14.6 m cd. (E) Basal diamicton, the position of the hand indicates the approximate end of the investigated section (20.9 m cd). (F) Example of a sediment bar cut manually in the thoroughly cleaned wall and thereafter sampled with a steel channel (left). The sediment bar covers 18.2-19.3 $\mathrm{m} \mathrm{cd}$.

Fig. 3. Composite sediment record compiled from XRF core-scanner photographs. The record covers a range from $0 \mathrm{~cm}$ cd (upper left) to $2099 \mathrm{~cm} \mathrm{~cd}$ (lower right). Magenta-coloured circles indicate the position of radiocarbon samples. White areas marked with a cross represent gravelrich sections lost during sampling.

Fig. 4. Element counts from XRF scanning (given in \% of total counts of significant elements), first principal component (PC1) of XRF data, and grain-size distribution of the composite profile.

Fig. 5. Principal components of ED-XRF analyses. Blue dots represent sediment samples from the composite sediment profile (numbers indicate $\mathrm{cm} \mathrm{cd}$ ). Red dots represent individual rock samples from the Berchtesgaden area stemming from the following formations: A: Allgäu Fm. (Jurassic basin sediments), D: Dachstein Fm., H: Hallstatt Fm., Ha: Haselgebirge Fm., O: Oberalm Fm., R: Ramsau dolomite (belonging to Wetterstein Fm.), Re: Reichenhall Fm., Ro: 
Roßfeld Fm., S: Schrambach Fm., T: Tauglboden Fm. (Jurassic basin sediments), W: Werfen Fm..

Fig. 6. Stacked $\mu$-XRF elemental maps of ground slabs from carbonate-rich layers in the Nesseltalgraben profile. The colours indicate the most abundant elements detected, $\mathrm{Mg}$ (purple), $\mathrm{Ca}$ (blue), and $\mathrm{Si}$ (green). The samples are from carbonate-rich layers at 78 (A), 780 (B), 926 (C), 1399 (D), 1599 (E), and 1712 (F) $\mathrm{cm} \mathrm{cd}$. The scale bar (100 $\mu \mathrm{m})$ in $\mathrm{F}$ is representative for all figures.

Fig. 7. Contents of organic and inorganic carbon (TOC, TIC), nitrogen (TN) and sulphur (TS) (black) compared to $\mathrm{S}$ and Ca data from XRF scans (blue).

Fig. 8. Median grain size, TIC, TOC, and distribution of lithotypes A-F in the composite profile. The thresholds used for lithotype definitions are indicated by dashed lines.

Fig. 9. Bacon age/depth model of the composite record using radiocarbon ages (blue) and the paleomagnetic excursion ascribed to the Laschamp event (green). Note the limit of radiocarbon calibration at 50,000 cal BP (dashed line). The stippled red line indicates the mean age-depth model, the grey stippled lines indicate the $95 \%$ confidence ranges, and the greyscales indicate the entire model, where darker grey represent more likely ages.

Fig. 10. (A) Calibrated radiocarbon ages (means and $2 \sigma$ ranges) from interstadial deposits in The Netherlands and (B) in the northern Alpine realm. (C) Rb/Sr, TOC, and PC 1 of elements from XRF scans from Nesseltalgraben (smoothed curves of PC1 and Rb/Sr filtered with $101 \mathrm{pt}$ and $23 \mathrm{pt}$ Gaussian filters, respectively). Oxygen isotope records of (D) Alpine speleothems (Hölloch, Moseley et al. 2014; Sieben Hengste cave system, Luetscher et al. 2015) and (E) Greenland ice core NGRIP (Rasmussen et al. 2014). (F) shows the $2 \sigma$ age errors of the respective records. Grey bars indicate inferred interstadials from the respective records, numbers in (E) the GIs (Rasmussen et al., 2014). Note the log scale of TOC and reverse scale of PC1. References for ${ }^{14} \mathrm{C}$ data in (A) and (B) are given in Table 3. 


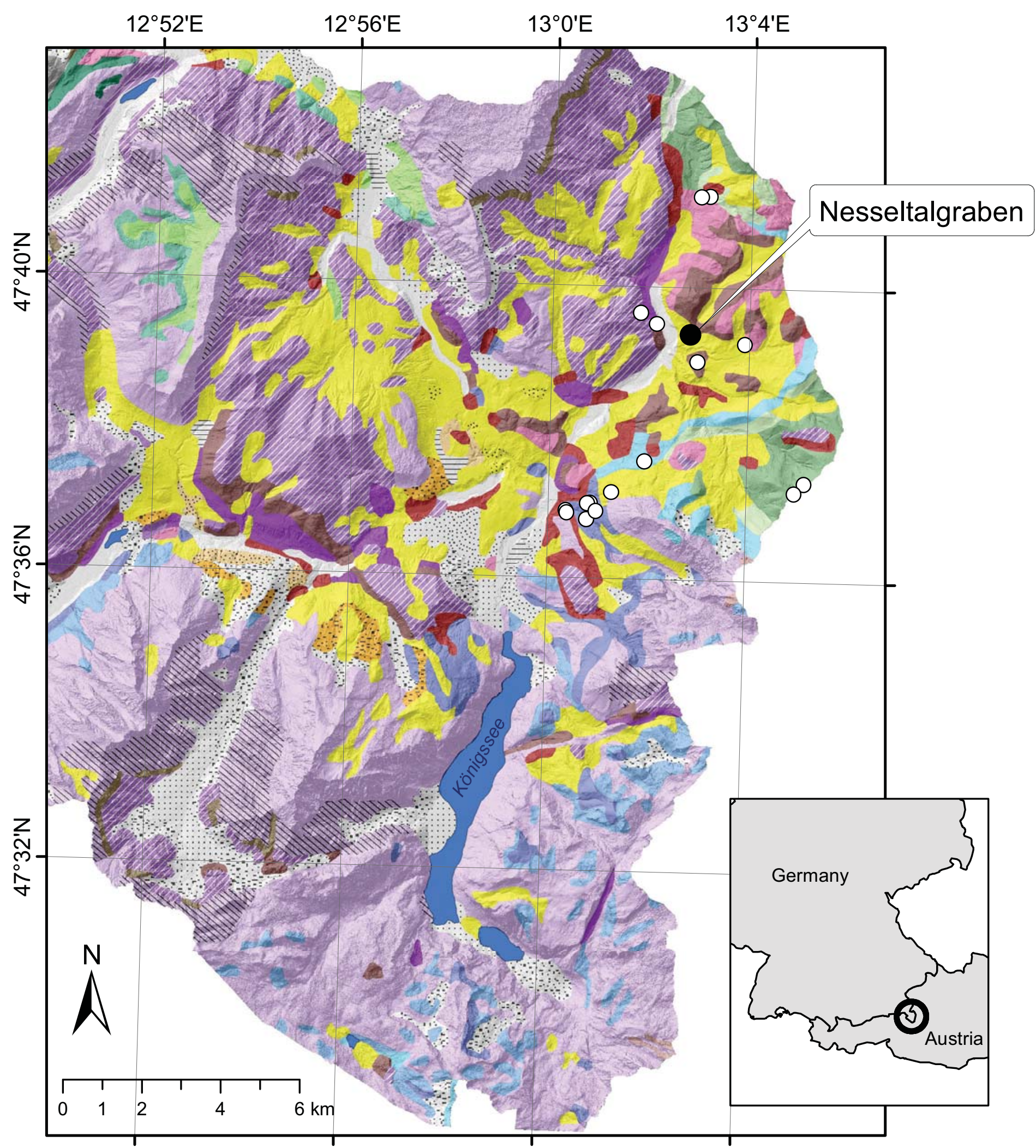

\section{Quaternary}

\begin{tabular}{|l|l}
\hline & Floodplain \\
\hline & Fen, bog \\
\hline & Talus, landslide \\
\hline & Alluvial fan \\
\hline & Würmian till \\
\hline & Würmian gravel \\
\hline & Rissian till \\
\hline & Rissian gravel \\
\hline & Mindelian-Rissian breccia
\end{tabular}

\section{Jurassic-Cretaceous}

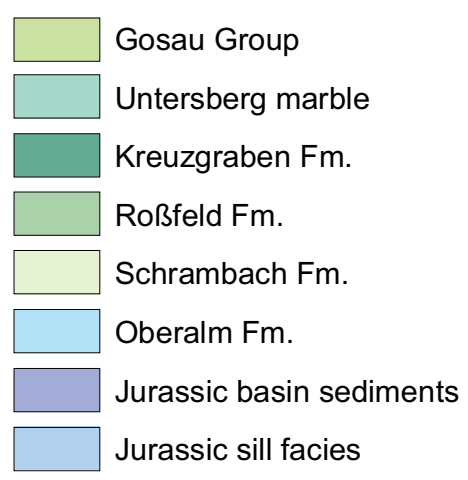

\section{Permian-Triassic}

Rhaetian marl and limestone

Dachstein Fm. limestone

D.VD Dachstein Fm. dolomite

Hallstatt Fm.

$\square$ Hauptdolomit

Raibl Fm.

Wetterstein Fm. dolomite

Reichenhall Fm.

Werfen Fm.

Haselgebirge 

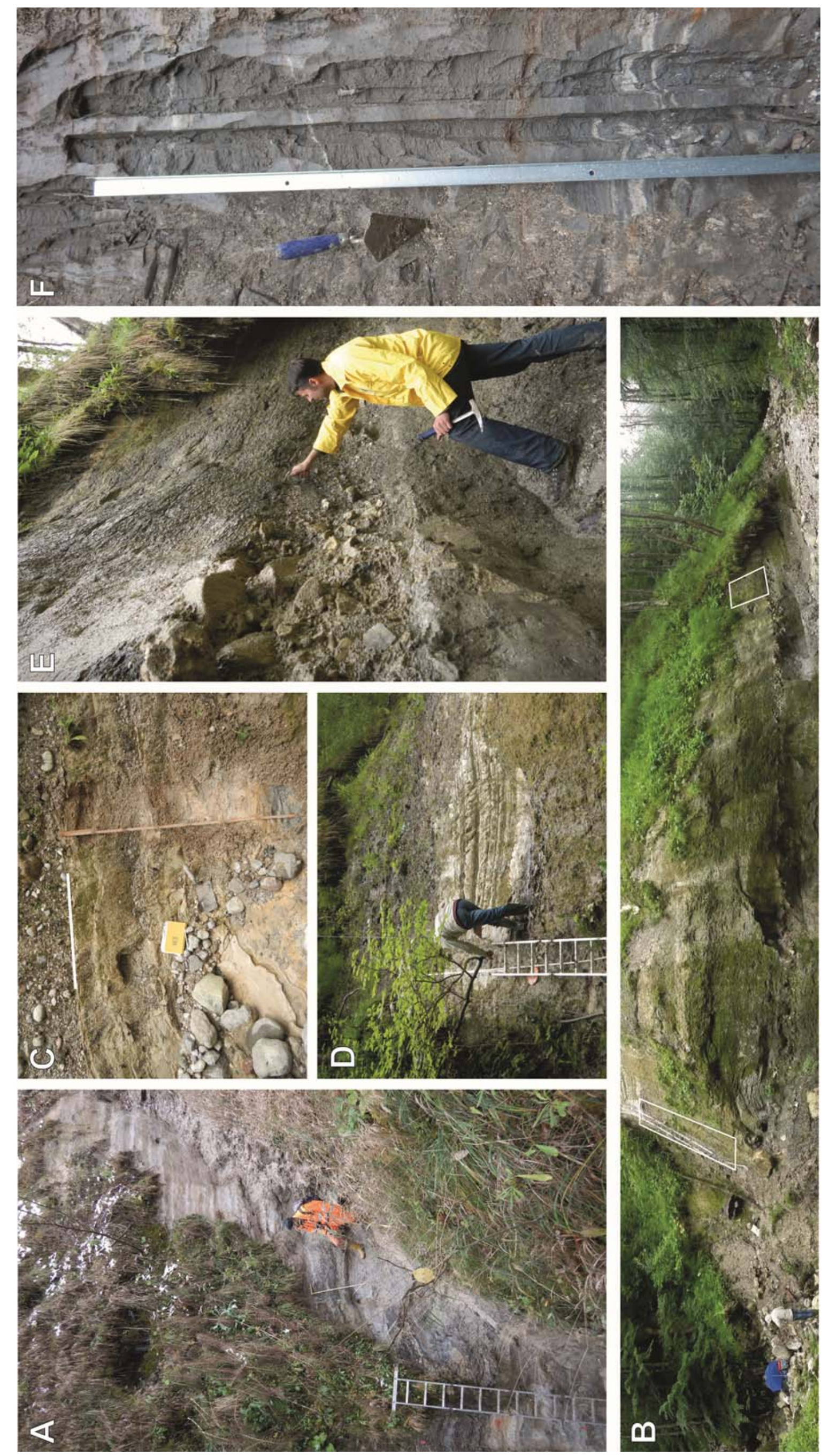
Composite depth $(\mathrm{cm})$

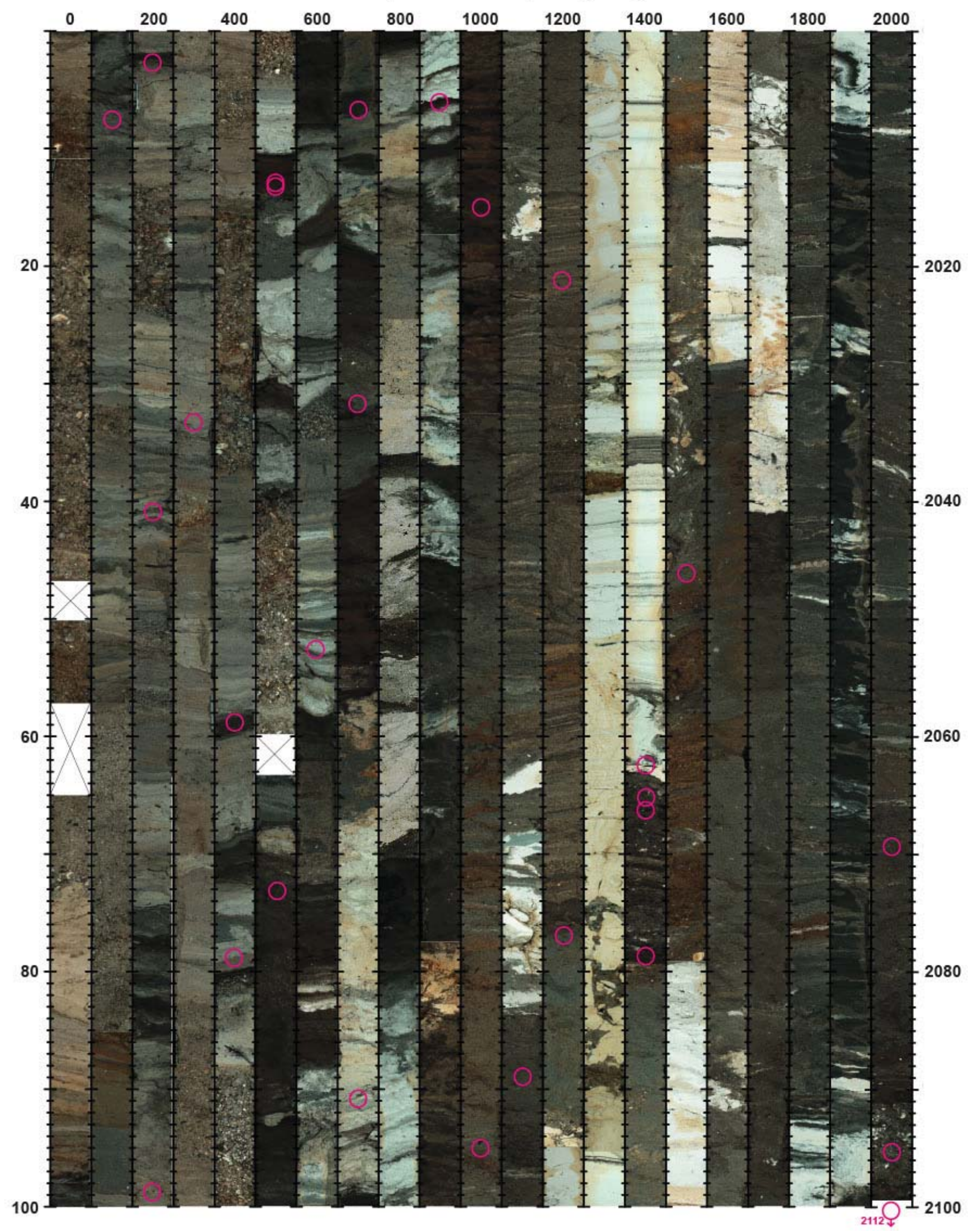









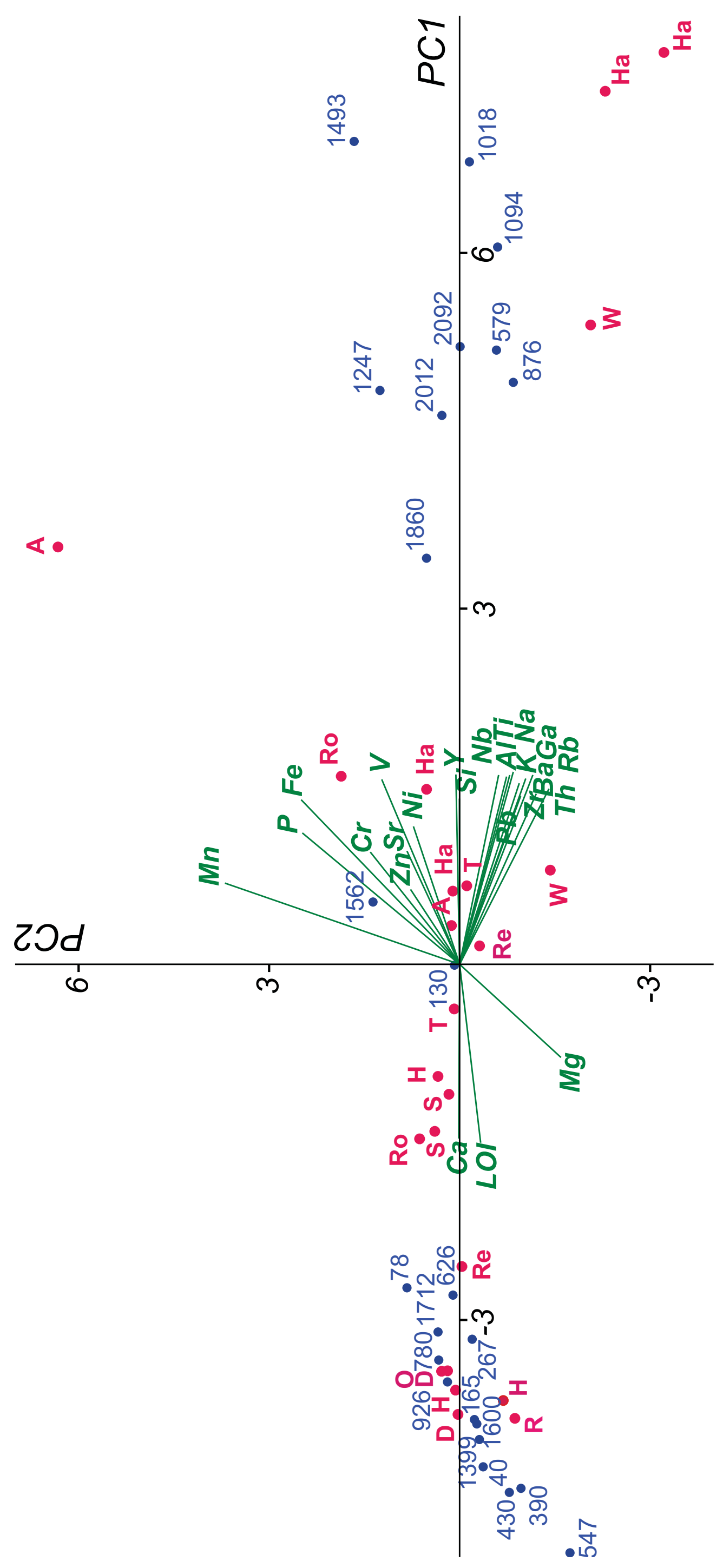



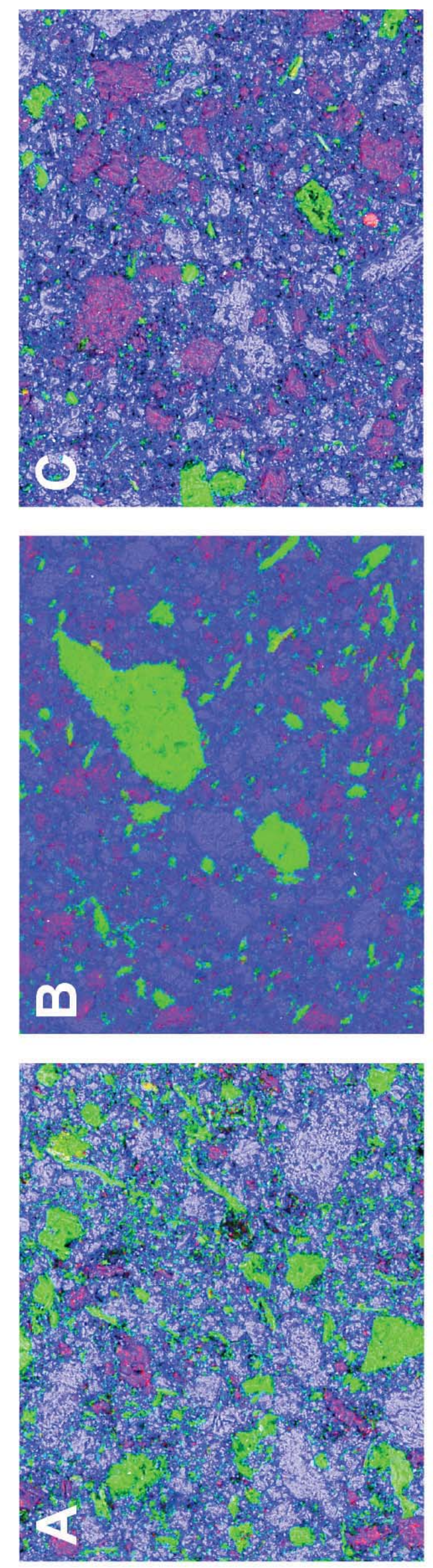
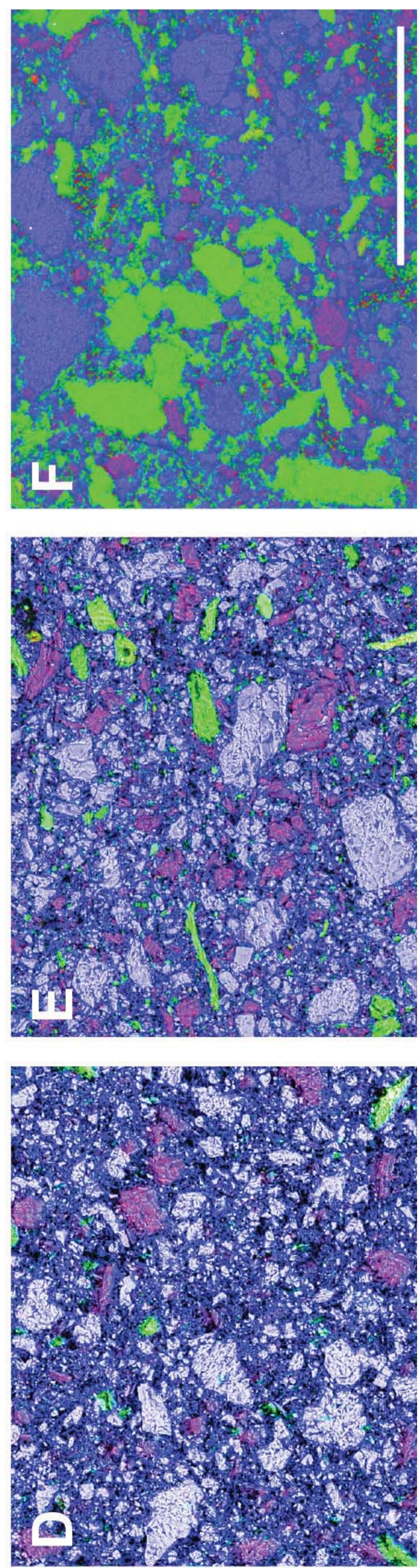


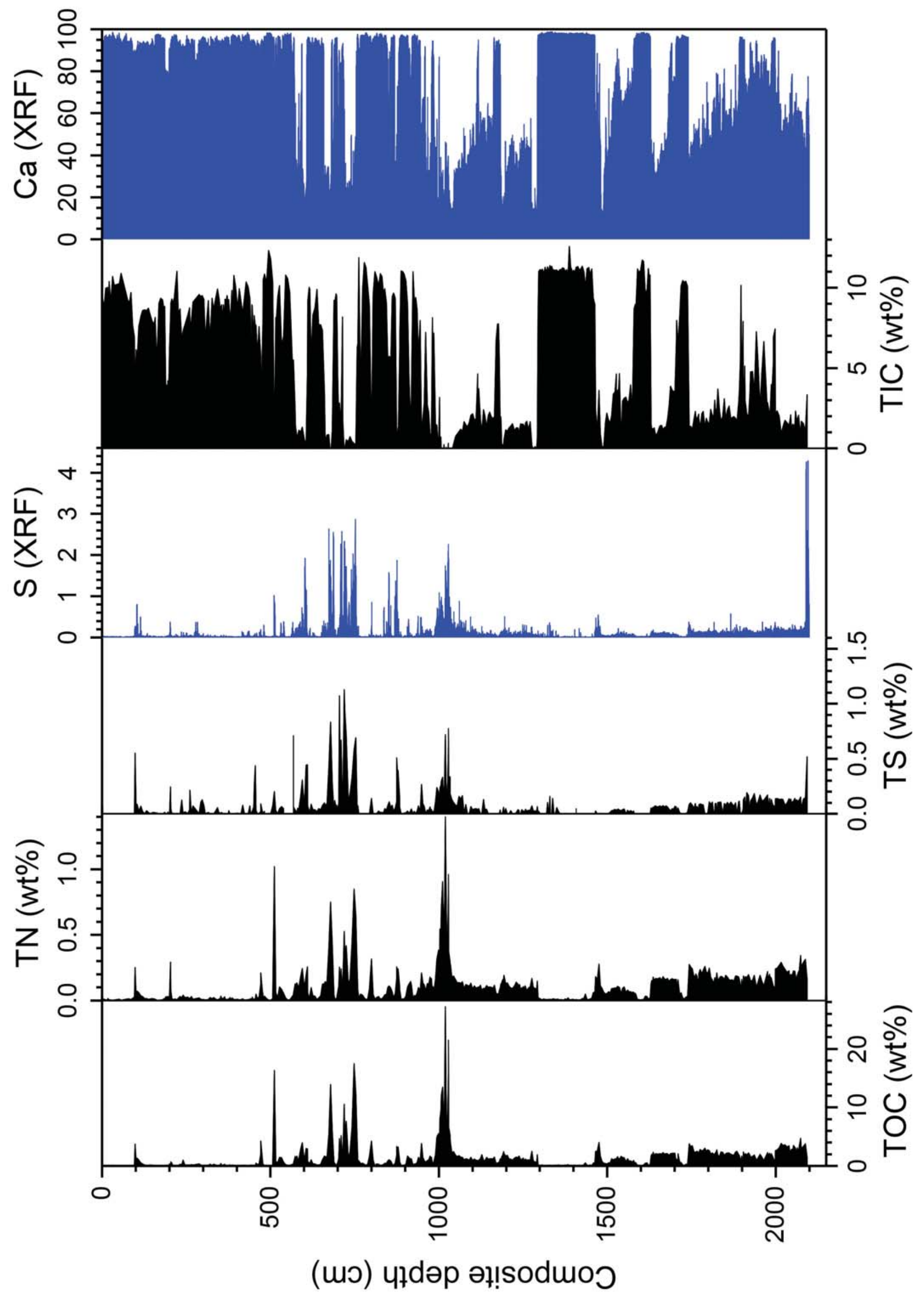



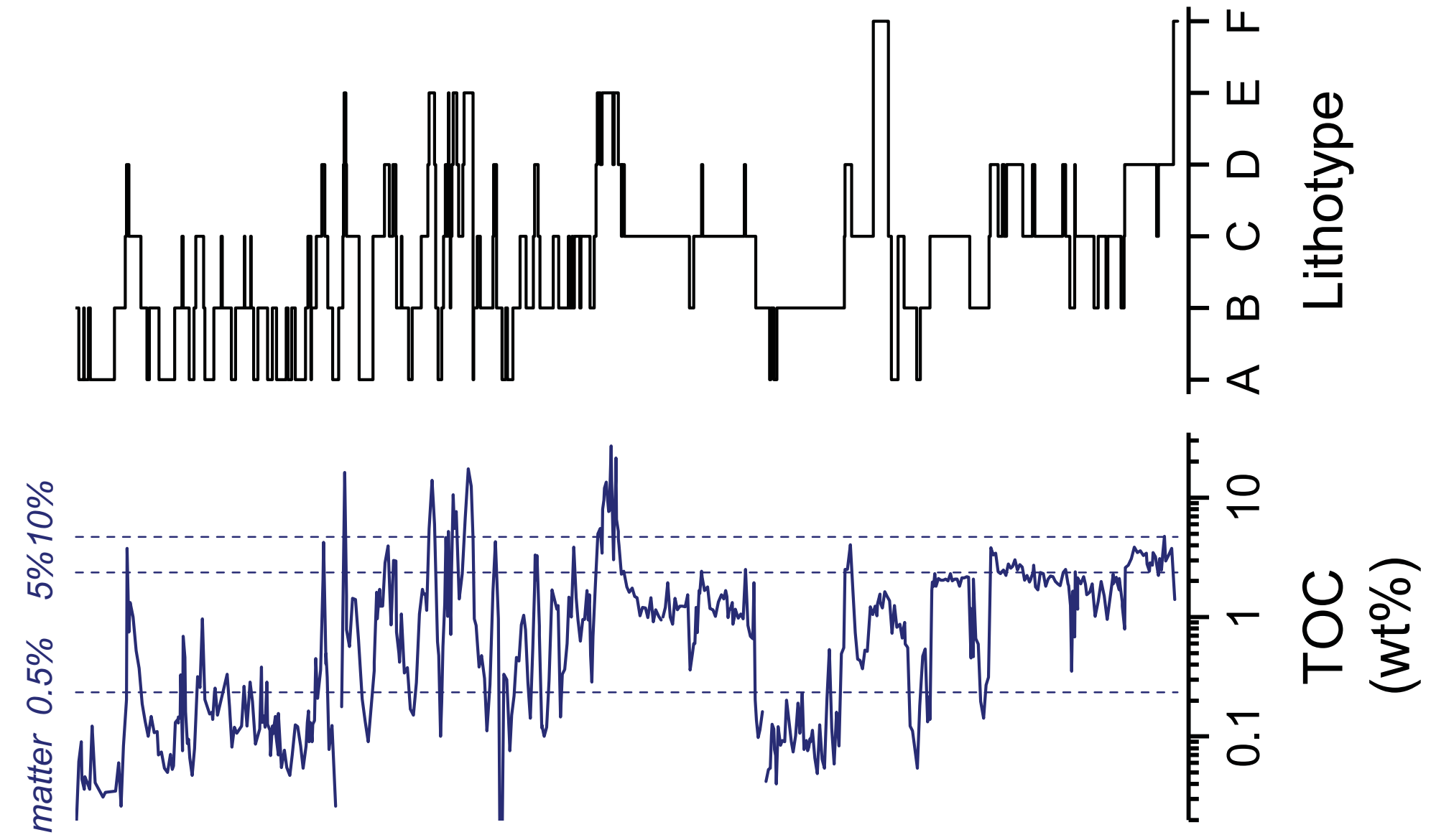

$\frac{0}{5}$
$\frac{0}{0}$

ว

ठ
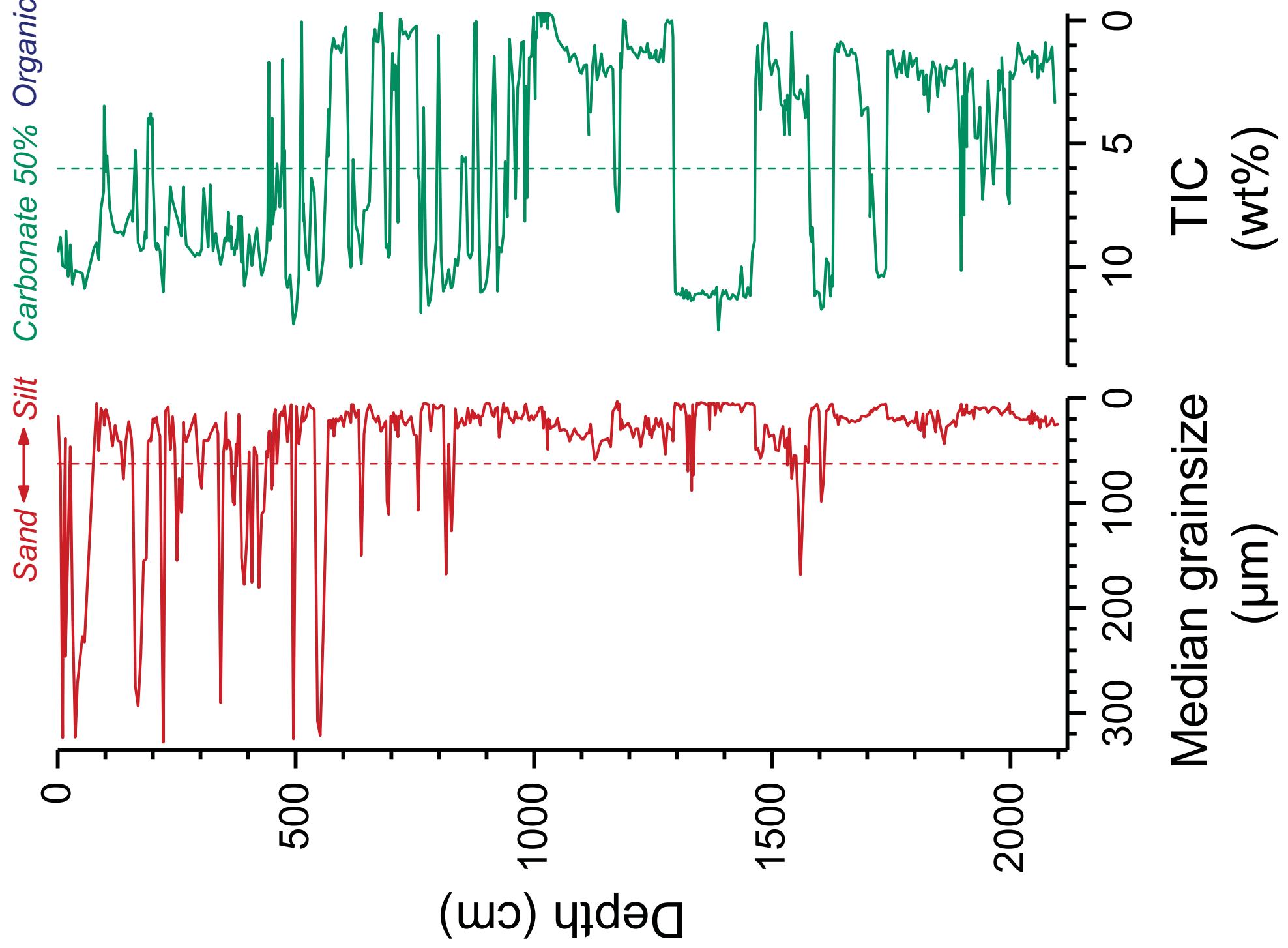


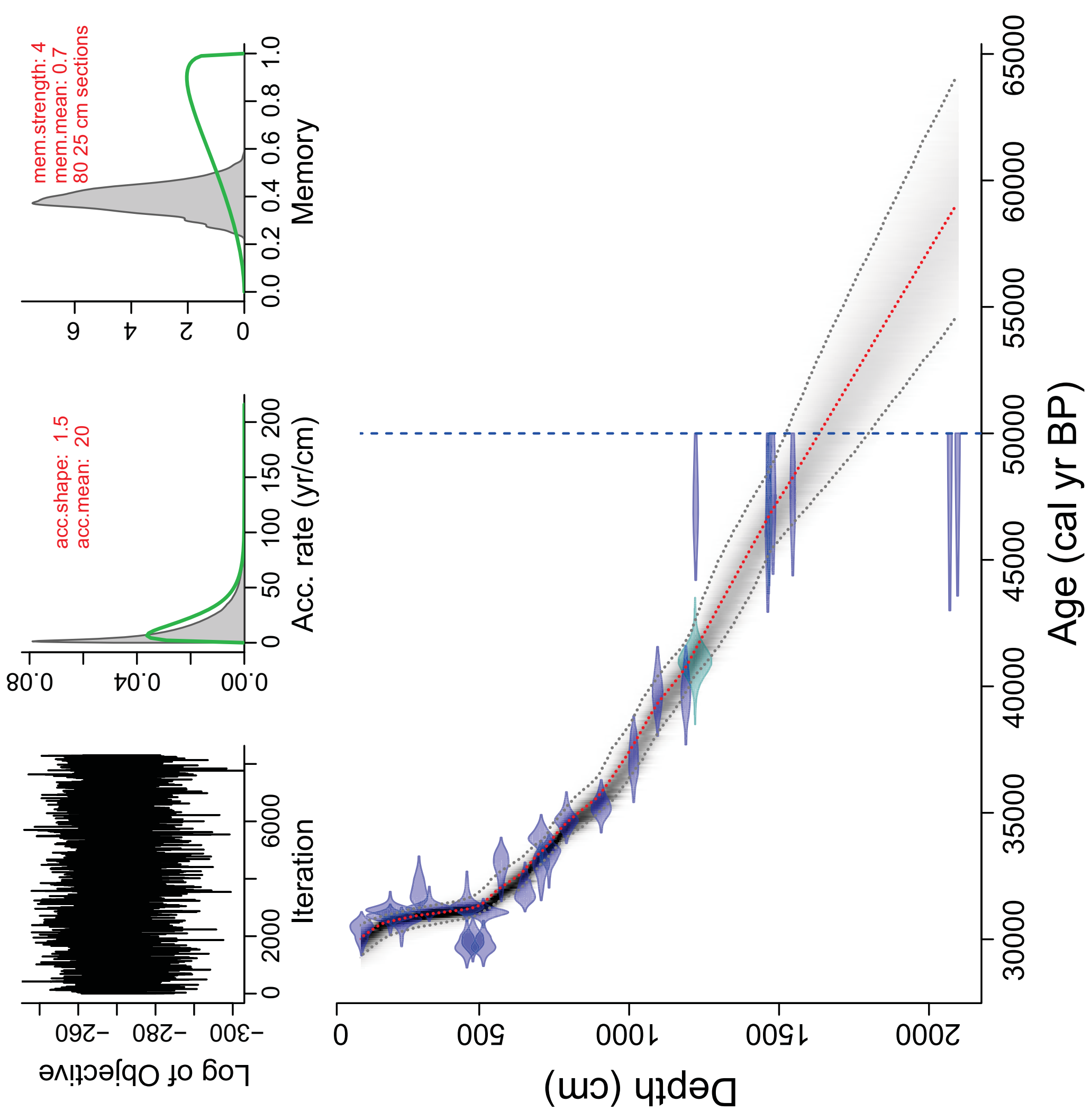




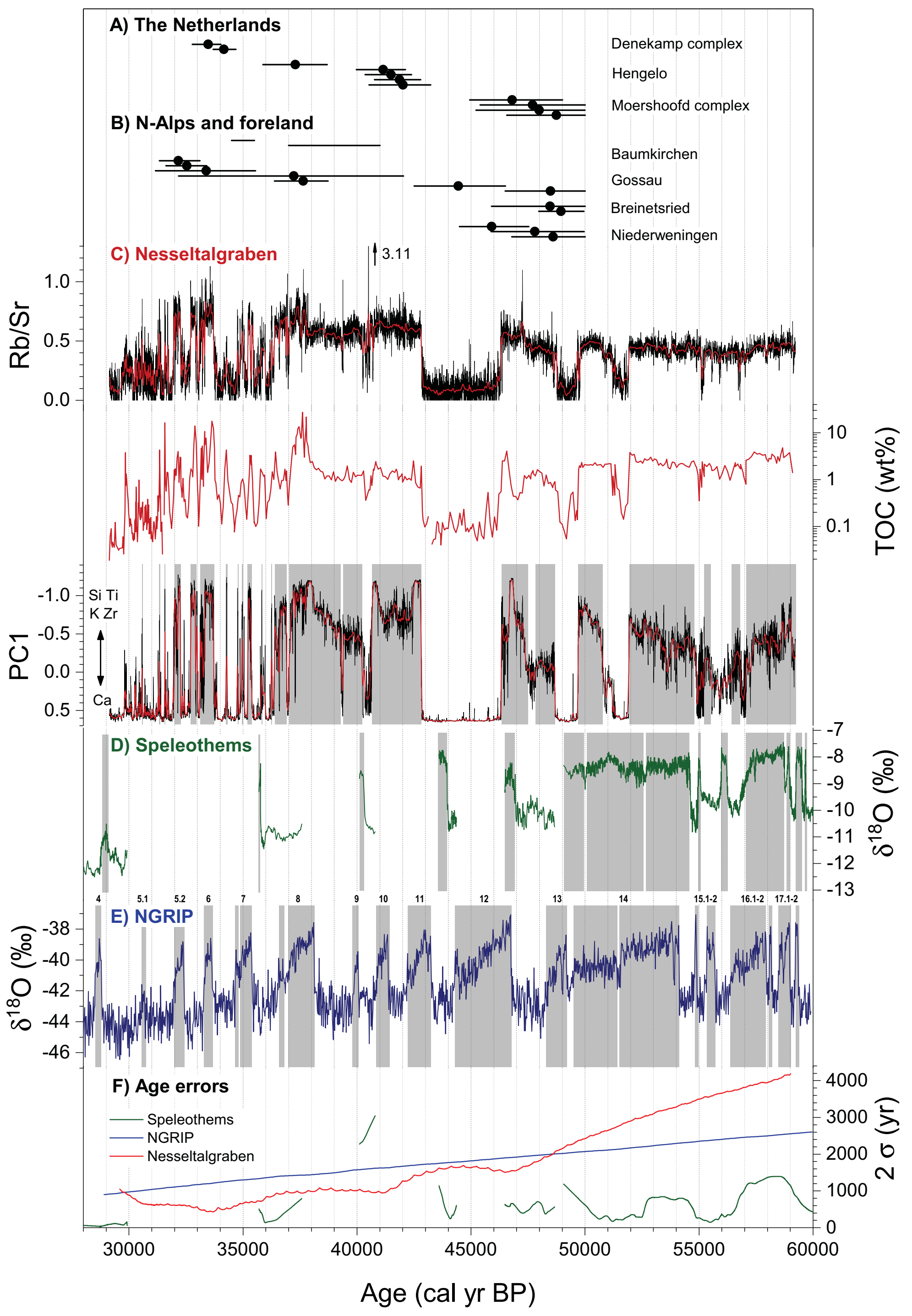


1 Table 1 Comparison of radiocarbon ages of samples pre-treated with ABA and ABOX from Nesseltalgraben.

2 ABA pre-treated samples are from Mayr et al. (2017).

3

\begin{tabular}{|c|c|c|c|c|c|c|c|}
\hline \multirow{2}{*}{$\begin{array}{c}\text { Sample } \\
\text { ID }\end{array}$} & \multicolumn{3}{|c|}{ Mayr et al. (2017) } & \multicolumn{3}{|c|}{ This study } & \multirow{2}{*}{$\begin{array}{c}\Delta \text { age } \\
\left({ }^{14} \mathrm{C}\right. \\
\mathrm{yr})\end{array}$} \\
\hline & $\begin{array}{l}\text { Laboratory } \\
\text { code }\end{array}$ & Material & $\begin{array}{c}\text { ABA age }\left({ }^{14} \mathrm{C}\right. \\
\text { yr BP) }\end{array}$ & $\begin{array}{l}\text { Laboratory } \\
\text { code }\end{array}$ & Material & $\begin{array}{c}\text { ABOX age }\left({ }^{14} \mathrm{C}\right. \\
\text { yr BP })\end{array}$ & \\
\hline \multirow[t]{2}{*}{ NE-7 } & \multirow[t]{2}{*}{ UBA-24910 } & \multirow{2}{*}{$\begin{array}{l}\text { twig from } \\
\text { peaty layer }\end{array}$} & \multirow[t]{2}{*}{$27111 \pm 234$} & UBA-24910-2 & twigs (NE-7B) & $26973 \pm 272$ & -138 \\
\hline & & & & UBA-24910-3 & mosses (NE-7A) & $27981 \pm 317$ & 870 \\
\hline NE-6 & UBA-24911 & $\begin{array}{c}\text { compressed } \\
\text { peat }\end{array}$ & $27206 \pm 234$ & UBA-24911 & plant remains & $27376 \pm 280$ & 170 \\
\hline $\mathrm{NE}-4$ & UBA-24902 & twig & $39611 \pm 783$ & UBA-24902 & wood & $40570 \pm 1391$ & 959 \\
\hline NE-5 & UBA-24903 & $\begin{array}{c}40 \mathrm{~cm} \text { long } \\
\text { piece of } \\
\text { wood }\end{array}$ & $43335 \pm 1100$ & UBA-24903 & wood & $47579 \pm 3865$ & 4244 \\
\hline NE-2 & Erl-17398 & $\begin{array}{c}\text { piece of } \\
\text { wood }\end{array}$ & $42167 \pm 1063$ & UBA-34046 & piece of a stem & $49109 \pm 4870$ & 6942 \\
\hline
\end{tabular}

4 


\section{Table 2}

2 Radiocarbon data from the composite profile. One outlier is marked with italics. Square brackets mark calibrated

3 values at the limit of the calibration curve. Values beyond the calibration period are marked with a dash.

\begin{tabular}{|c|c|c|c|c|c|c|c|}
\hline $\begin{array}{l}\text { Sample } \\
\text { ID }\end{array}$ & $\begin{array}{l}\text { Laborator } \\
\text { y code }\end{array}$ & $\begin{array}{l}\text { Material } \\
\text { Type }\end{array}$ & $\begin{array}{c}\text { Conventiona } \\
\mathrm{I}^{14} \mathrm{C} \text { age }\left({ }^{14} \mathrm{C}\right. \\
\text { yr BP })\end{array}$ & $\mathrm{F}^{14} \mathrm{C}$ & $\begin{array}{l}\text { Calibrated }{ }^{14} \mathrm{C} \text { age } \\
\text { range (cal } \mathrm{BP}, 2 \sigma)\end{array}$ & $\begin{array}{l}\text { Mean } \\
\text { depth } \\
\text { (cm cd) }\end{array}$ & $\begin{array}{l}\text { Sample } \\
\text { thicknes } \\
\text { s (cm cd) }\end{array}$ \\
\hline $\begin{array}{c}\text { NTGRC } \\
-28\end{array}$ & $\begin{array}{l}\text { UBA- } \\
37036\end{array}$ & $\begin{array}{c}\text { plant } \\
\text { debris } \\
\text { (mainly } \\
\text { monocots } \\
\text { ) }\end{array}$ & $26,130 \pm 227$ & $0.0387 \pm 0.0011$ & $29,750-30,880$ & 107.5 & 1.9 \\
\hline $\begin{array}{c}\text { NTGRC } \\
-15\end{array}$ & $\begin{array}{c}\text { UBA- } \\
35876\end{array}$ & mosses & $27,222 \pm 215$ & $0.0338 \pm 0.0009$ & $30,890-31,440$ & 203.2 & 1.6 \\
\hline $\begin{array}{c}\text { NTGRC } \\
-16\end{array}$ & $\begin{array}{c}\text { UBA- } \\
35877\end{array}$ & monocots & $26,726 \pm 197$ & $0.0359 \pm 0.0009$ & $30,620-31,170$ & 203.2 & 1.6 \\
\hline $\begin{array}{c}\text { NTGRC } \\
-17\end{array}$ & $\begin{array}{c}\text { UBA- } \\
35878\end{array}$ & $\begin{array}{c}\text { plant } \\
\text { debris }\end{array}$ & $26,488 \pm 194$ & $0.0370 \pm 0.0009$ & $30,360-31,070$ & 241.0 & 1.6 \\
\hline $\begin{array}{c}\text { NTGRC } \\
-13\end{array}$ & $\begin{array}{c}\text { UBA- } \\
34037\end{array}$ & $\begin{array}{l}\text { small } \\
\text { twigs }\end{array}$ & $28,032 \pm 296$ & $0.0305 \pm 0.0011$ & $31,260-32,740$ & 299.0 & 1.0 \\
\hline $\begin{array}{c}\text { NTGRC } \\
-18\end{array}$ & $\begin{array}{c}\text { UBA- } \\
35879\end{array}$ & $\begin{array}{c}\text { plant } \\
\text { debris }\end{array}$ & $27,367 \pm 211$ & $0.0332 \pm 0.0009$ & $30,970-31,540$ & 333.4 & 1.8 \\
\hline $\begin{array}{c}\text { NTGRC } \\
-19\end{array}$ & $\begin{array}{c}\text { UBA- } \\
35880\end{array}$ & mosses & $25,592 \pm 186$ & $0.0413 \pm 0.0010$ & $29,240-30,360$ & 458.9 & 1.8 \\
\hline $\begin{array}{c}\text { NTGRC } \\
-20\end{array}$ & $\begin{array}{c}\text { UBA- } \\
35881\end{array}$ & monocots & $27,465 \pm 278$ & $0.0328 \pm 0.0011$ & $30,930-31,820$ & 458.9 & 1.8 \\
\hline $\begin{array}{c}\text { NTGRC } \\
-21\end{array}$ & $\begin{array}{c}\text { UBA- } \\
35882\end{array}$ & mosses & $25,767 \pm 179$ & $0.0404 \pm 0.0009$ & $29,460-30,530$ & 478.8 & 2.0 \\
\hline $\begin{array}{c}\text { NTGRC } \\
-23\end{array}$ & $\begin{array}{c}\text { UBA- } \\
35884\end{array}$ & monocots & $27,021 \pm 210$ & $0.0346 \pm 0.0009$ & $30,790-31,320$ & 513.5 & 2.0 \\
\hline $\begin{array}{c}\text { NTGRC } \\
-22\end{array}$ & $\begin{array}{c}\text { UBA- } \\
35883\end{array}$ & $\begin{array}{c}\text { plant } \\
\text { debris }\end{array}$ & $25,611 \pm 175$ & $0.0412 \pm 0.0009$ & $29,290-30,350$ & 514.0 & 2.0 \\
\hline $\begin{array}{c}\text { NTGRC } \\
-11\end{array}$ & $\begin{array}{c}\text { UBA- } \\
34038\end{array}$ & $\begin{array}{c}\text { piece of a } \\
\text { small } \\
\text { stem }\end{array}$ & $28,893 \pm 330$ & $0.0274 \pm 0.0011$ & $31,960-33,760$ & 573.0 & 1.0 \\
\hline $\begin{array}{c}\text { NTGRC } \\
-24\end{array}$ & $\begin{array}{c}\text { UBA- } \\
35891 \\
\end{array}$ & monocots & $28,035 \pm 232$ & $0.0305 \pm 0.0009$ & $31,320-32,600$ & 652.7 & 1.9 \\
\hline $\begin{array}{c}\text { NTGRC } \\
-25 \\
\end{array}$ & $\begin{array}{c}\text { UBA- } \\
35892 \\
\end{array}$ & mosses & $29,914 \pm 311$ & $0.0241 \pm 0.0009$ & $33,520-34,590$ & 706.6 & 1.8 \\
\hline $\begin{array}{c}\text { NTGRC } \\
-26\end{array}$ & $\begin{array}{c}\text { UBA- } \\
35893\end{array}$ & monocots & $28,825 \pm 279$ & $0.0276 \pm 0.0009$ & $32,000-33,660$ & 706.6 & 1.8 \\
\hline $\begin{array}{c}\text { NTGRC } \\
-29\end{array}$ & $\begin{array}{c}\text { UBA- } \\
37037\end{array}$ & monocots & $29,202 \pm 259$ & $0.0264 \pm 0.0008$ & $32,770-33,910$ & 732.8 & 1.9 \\
\hline $\begin{array}{c}\text { NTGRC } \\
-30 \\
\end{array}$ & $\begin{array}{c}\text { UBA- } \\
37038 \\
\end{array}$ & mosses & $30,782 \pm 308$ & $0.0217 \pm 0.0008$ & $34,110-35,320$ & 790.8 & 1.8 \\
\hline $\begin{array}{c}\text { NTGRC } \\
-31\end{array}$ & $\begin{array}{c}\text { UBA- } \\
37039\end{array}$ & monocots & $31,333 \pm 317$ & $0.0202 \pm 0.0008$ & $34,630-35,920$ & 906.7 & 1.5 \\
\hline $\begin{array}{c}\text { NTGRC } \\
-2\end{array}$ & $\begin{array}{c}\text { UBA- } \\
34039\end{array}$ & $\begin{array}{c}\text { piece of a } \\
\text { small } \\
\text { stem }\end{array}$ & $32,956 \pm 532$ & $0.0165 \pm 0.0011$ & $35,890-38,480$ & 1015.0 & 1.0 \\
\hline $\begin{array}{c}\text { NTGRC } \\
-27 \\
\end{array}$ & $\begin{array}{c}\text { UBA- } \\
35894\end{array}$ & small twig & $35,219 \pm 632$ & $0.0125 \pm 0.0009$ & $38,510-41,150$ & 1094.8 & 1.0 \\
\hline $\begin{array}{l}\text { NTGRC } \\
-5\end{array}$ & $\begin{array}{l}\text { UBA- } \\
34040\end{array}$ & $\begin{array}{l}\text { piece of a } \\
\text { small } \\
\text { stem } \\
\text { (conifer) }\end{array}$ & $35,163 \pm 697$ & $0.0126 \pm 0.0010$ & $38,340-41,280$ & 1189.0 & 1.0 \\
\hline $\begin{array}{c}\text { NTGRC } \\
-4\end{array}$ & $\begin{array}{c}\text { UBA- } \\
37043\end{array}$ & wood & $43,851 \pm 1538$ & $0.0043 \pm 0.0007$ & $44,800-[49,990]$ & 1222.0 & 1.0 \\
\hline $\begin{array}{c}\text { NTGRC } \\
-32 \\
\end{array}$ & $\begin{array}{c}\text { UBA- } \\
37040\end{array}$ & monocots & $31,033 \pm 445$ & $0.0210 \pm 0.0011$ & $34,130-35,860$ & 1277.4 & 1.6 \\
\hline
\end{tabular}




\begin{tabular}{|c|c|c|c|c|c|c|c|}
\hline $\begin{array}{c}\text { NTGRC } \\
-3\end{array}$ & $\begin{array}{l}\text { UBA- } \\
34041\end{array}$ & $\begin{array}{c}\text { piece of a } \\
\text { small } \\
\text { stem }\end{array}$ & $42,882 \pm 1894$ & $0.0048 \pm 0.0010$ & $43,270-49,700$ & 1462.5 & 1.0 \\
\hline $\begin{array}{c}\text { NTGRC } \\
-6\end{array}$ & $\begin{array}{l}\text { UBA- } \\
34042\end{array}$ & $\begin{array}{c}\text { piece of a } \\
\text { small } \\
\text { stem } \\
\text { (conifer) }\end{array}$ & $45,206 \pm 2644$ & $0.0036 \pm 0.0010$ & $44,130-[50,000]$ & 1465.0 & 1.0 \\
\hline $\begin{array}{c}\text { NTGRC } \\
-8 \\
\end{array}$ & $\begin{array}{l}\text { UBA- } \\
37044\end{array}$ & $\begin{array}{l}\text { wood } \\
\text { (Pinus) }\end{array}$ & $43,452 \pm 1421$ & $0.0045 \pm 0.0007$ & $44,390-49,670$ & 1466.5 & 7.0 \\
\hline $\begin{array}{c}\text { NTGRC } \\
-33\end{array}$ & $\begin{array}{c}\text { UBA- } \\
37041\end{array}$ & twig & $44,202 \pm 1567$ & $0.0041 \pm 0.0007$ & $45,070-[50,000]$ & 1480.0 & 1.6 \\
\hline $\begin{array}{c}\text { NTGRC } \\
-34\end{array}$ & $\begin{array}{c}\text { UBA- } \\
37042\end{array}$ & $\begin{array}{c}\text { wood } \\
\text { particles }\end{array}$ & $44,327 \pm 1685$ & $0.0040 \pm 0.0008$ & $44,990-[50,000]$ & 1545.7 & 1.6 \\
\hline $\begin{array}{c}\text { NTGRC } \\
-9\end{array}$ & $\begin{array}{l}\text { UBA- } \\
34043\end{array}$ & $\begin{array}{c}\text { piece of a } \\
\text { small } \\
\text { stem }\end{array}$ & $49,293 \pm 5031$ & $0.0022 \pm 0.0010$ & -- & 2069.5 & 1.0 \\
\hline $\begin{array}{c}\text { NTGRC } \\
-7\end{array}$ & $\begin{array}{l}\text { UBA- } \\
34044\end{array}$ & $\begin{array}{c}\text { small } \\
\text { stem } \\
\text { (Betula or } \\
\text { Alnus) }\end{array}$ & $46,986 \pm 3440$ & $0.0029 \pm 0.0010$ & -- & 2095.5 & 1.0 \\
\hline $\begin{array}{c}\text { NTGRC } \\
-14\end{array}$ & $\begin{array}{l}\text { UBA- } \\
34045\end{array}$ & $\begin{array}{c}\text { piece of a } \\
\text { small } \\
\text { stem }\end{array}$ & -- & -- & -- & 2112.0 & 1.0 \\
\hline
\end{tabular}

5 


\section{Table 3}

Radiocarbon data from sites in The Netherlands and the Northern Alps and their foreland. Only ages within the calibration period are listed. Square brackets mark calibrated values at the limit of the calibration curve.

\begin{tabular}{|c|c|c|c|}
\hline Site & $\begin{array}{c}\text { Conventional }{ }^{14} \mathrm{C} \text { age } \\
\left({ }^{14} \mathrm{C} \text { yr BP }\right)\end{array}$ & $\begin{array}{l}\text { Calibrated }{ }^{14} \mathrm{C} \text { age } \\
\text { range (cal } \mathrm{BP}, 2 \sigma)\end{array}$ & Reference \\
\hline Dinkel valley & $29,300 \pm 300$ & $32,770-34,030$ & $\begin{array}{c}\text { Van der Hammen, et al., 1967; Van der } \\
\text { Hammen, } 1971\end{array}$ \\
\hline Dinkel valley & $30,100 \pm 300$ & $33,690-34,680$ & Van der Hammen, 1971 \\
\hline Hengelo A1 & $33,100 \pm 600$ & $35,880-38,700$ & Vandenberghe \& Van der Plicht, 2016 \\
\hline Hengelo KNZ & $36,600 \pm 600$ & $39,970-42,130$ & Vandenberghe \& Van der Plicht, 2016 \\
\hline Breda & $37,000 \pm 600$ & $40,350-42,390$ & Vandenberghe \& Van der Plicht, 2016 \\
\hline Hengelo Rientjes & $37,500 \pm 650$ & $40,760-42,790$ & Vandenberghe \& Van der Plicht, 2016 \\
\hline Grouw & $37,750 \pm 850$ & $40,520-43,230$ & Vandenberghe \& Van der Plicht, 2016 \\
\hline Moershoofd & $43,500 \pm 1,000$ & $44,940-49,010$ & $\begin{array}{c}\text { Zagwijn, 1961; Van der Hammen et al., } \\
1967\end{array}$ \\
\hline Moershoofd & $44,500 \pm 1,500$ & $45,400-[50,000]$ & Zagwijn, 1961 \\
\hline Groot Duckenburg & $45,300 \pm 2,000$ & $45,220-[50,000]$ & $\begin{array}{l}\text { Teunissen and Teunissen-van Oorschot, } \\
1974\end{array}$ \\
\hline Moershoofd & $46,250 \pm 1,500$ & $46,560-[50,000]$ & $\begin{array}{l}\text { Zagwijn, 1961; Van der Hammen et al., } \\
1967\end{array}$ \\
\hline Baumkirchen PZ6 & Not reported & c. $34,500-35,500$ & Barrett et al., 2018 \\
\hline Baumkirchen PZ4 & Not reported & c. $37,000-41,000$ & Barrett et al., 2018 \\
\hline Gossau 3 (top) & $28,550 \pm 310$ & $31,620-33,410$ & Schlüchter et al, 1987 \\
\hline Gossau 3 (top) & $29,450 \pm 1,150$ & $31,170-35,550$ & Schlüchter et al, 1987 \\
\hline Gossau 3 (base) & $28,250 \pm 350$ & $31,340-33,110$ & Schlüchter et al, 1987 \\
\hline Gossau 2 (top) & $33,000 \pm 2,500$ & $32,170-42,040$ & Schlüchter et al, 1987 \\
\hline Gossau 2 (top) & $33,410 \pm 480$ & $36,378-38,740$ & Schlüchter et al, 1987 \\
\hline Gossau 2 (base) & $40,920 \pm 1,220$ & $42,500-46,510$ & Schlüchter et al, 1987 \\
\hline Gossau 1 (top) & $45,420 \pm 1,200$ & $46,500-[50,000]$ & Schlüchter et al, 1987 \\
\hline Breinetsried I (top) & $45,500 \pm 400$ & $47,970-49,950$ & Grootes, 1977; Peschke, 1983 \\
\hline Breinetsried I & $46,300+2,200 /-1,700$ & $45,900-[50,000]$ & Grootes, 1979 \\
\hline $\begin{array}{c}\text { Niederweningen } \\
\text { upper peat }\end{array}$ & $42,620 \pm 780$ & $44,489-47,530$ & Hajdas et al, 2007 \\
\hline $\begin{array}{c}\text { Niederweningen } \\
\text { upper peat }\end{array}$ & $44,520 \pm 1,140$ & $45,880-49,960$ & Hajdas et al, 2007 \\
\hline $\begin{array}{c}\text { Niederweningen } \\
\text { middle peat }\end{array}$ & $45,430 \pm 1,020$ & $46,790-[50,000]$ & Hajdas et al, 2007 \\
\hline
\end{tabular}

